しては術中門脈王計揤の意味がなくなることがある。

以上我↔は Swan Ganz Catheter を用い6 例の脾摘を 行なった. 本法は脾摘のみならす，脾预脈瘤，脾動静脈 瘦，腄損賃等八の応用子考えられる。

\section{坐镸のまとめ}

櫢松 俊夫

私の担当したせッションは脾に関する 7 題の演題があ った. 109庶は名古屋市厚生病院松垣氏らにより脾腄に とむな5脾動脈瘤の氏らの症例をむとに内外の報告例に ついて検討された，これに対し千葉大第 2 外科平島氏よ り脾尰に脾動脈留を合併した 3 例の追加があり，また東

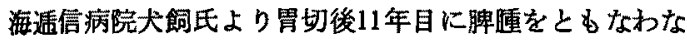
、脾動脈瘤の滕管への穿破例の追加がなされ注目され た. ともかく最近は血管造影が広く行なかれて捄り脾動 脈溜の発見される数む増加するであるらし，また破裂前 に適切な処唄がとられる機会るらえるであるら１10， 111，112席は HS, AIHA，慢性 ITP の臨床所見ならび に摘脾の效果とその時期について鳥取大第 1 外科中尾氏 ら，川崎医大润谷氏ら，関東透信病院高橋氏らによって 夫々検討報告されれたＨS に関してはその摘脾効果が 充分満足すべきのから, 新生児・乳児以外は HS と 診断されたら摘脾をただちに行ならという附加的説明が 川㱦医大堀谷氏よりなされた、AIHA 怙よび ITPでは ステロイドが第一選択であり，それが有効であれば長期 につづけることに異諭はなかったが，ステロイドが無効 があるいはあまり奻果がないばあいステロイド療法を゙ 具体的にどらするか（投与量，投与期間）：免疫抑制剂 の併用をどらするか，摘脾の時期をどのように決定する
かについて馀議されたが川猗医大倜谷氏は血液内科との 咕調のむとに種々の検查項目を検討し個々に決定すると の見解を示した. 関東逓信病院高橋氏らは慢性 ITP 患 者の細胞免疫能が六進しているとの興味ある報告をされ たが，この問顥は今後さらに検討されて ITP 発症に関 する細胞免疫学的役割について解明されることが望まれ る. 113席は名古屋第 1 赤十字病院宮田氏らにより CML に対する摘脾について報告されたが，CML では原則と して摘脾が適応であること，手術時期は発症後可及的す みやかに行なかれるのが望ましいとの氏の見解が示され た.114席は東海派信病院犬飼氏らによって脾の巽型悪 性細網症の症例が報告され，札幌医大 1 外平田氏より術 後䀒病変の起因ならびに術後糖尿病合併の有無について 筫疑がなされた，それに対して犬飼氏ょり糖疗病の合併 なくまた術後の肝病变は術前からあった肝転移の增大 によるるのであるとの解答がよせられていた，115席は 摘脾の手技に関する演題で輿大消化器外科石田氏らに よって報告された：その方法はあらかしめ Swan Ganz Catheterで脾動脈を閉塞して特き脾を虚血状龍にして 手術を行ならむので，それによって出血量の減少，脾腫 の縮少，手技の容易化など多くの利点が報告されたここ れに対して名古屋保健衛生大，青林より氏自身は経験 ないが手術手技を容易化するためには役立つであるちと の見解がよせられ，また氏より手術操作の最初に腪動脈 の結紫を同様の目的で行なっているとの追加がなされ た.

\title{
第I会場 午前の部
}

\section{小児・頚・胸部 (III-84 88) 座長 沢口 重徳 II-84.小児における碩部疾㭧の経験}

東京慈恵会医科大学第 1 外科

山崎 洋次, 策原勝, 斉藤玻瑠夫
五藤 仁, 立原 慶德, 䃇買 詰

成人・小児を問わず，日常の外来を訪れる患者のう ち，頊部の異常を主訴とするるのは少なくない。これら 預部疾患のうちには，腫瘤の存在部位や性状などの理学 的所見だけでは確定猃断不能な例るあり，また沿㞠に関 してる検討の余地がある.そこでわれわれは，東京慈恵 会医科大学第 1 外科において経験した小児預部疾患を検 索し，成人に怙汁る場合との相違点，詮断・治療上配虑
すべき事項などを明らかにしたい。

検討の対象上なった症例は，当科において1967年 1 月 から1977年12月までの11年間に経験した15藏以下の頊部 疾患275例であるが，頝部領域に括ける外傷例は対象か ら除外した.これら275例のらち，甲状腺以外の䫓部 疾患は245例 (89\%) で，甲状腺疾患は30例 (11\%)で あった.

非甲状腺疾患の5ち，炎症性疾患は139例で，全症例 の約50\%に相当した，139例の内わけは，単純性リンパ 節炎 48例，急性化啧性りンパ節炎53例，結核性リンパ節

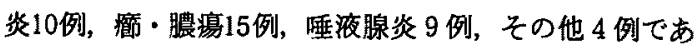
った. 化膿性炎症性疾患の起桨菌のほとんどは, いわゆ 
る耐性ブ菌であった，甲状腺に由来しない頝部腫璄は， リンバ管腫16例, 血管腫12例, 粉瘤, 石灰化上皮腫など の良性腫瘍11例，悪性リンパ重，横紋筋肉腫などの悪性 腫場 5 例の計44例であった.リンハ管䚙に関しては，治 療上赫涉させられる症例が少なくなかった，先天性奇形

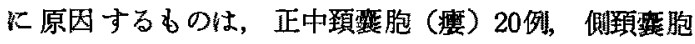

(㾇) 7 例，耳介㿉孔 4 例，副耳 2 例の計33例であ。 t.

甲状腺疾患は30例で，その内わけは単純性甲状腺腫18 例，甲状腺機能六進症 6 例，甲状腺炎 5 例，甲状腺機能 低下症 1 例であり，甲状腺癌の症例はない，成人の甲状 腺疾患に比較すると，数は少なく疾患の質としても，連 㴼や機能障害疾患の少ない煩向がうかがかれる。

\section{III-85. 乳児先天性心疾患に対する外科治寮} 札幌医大胸部外科

○安哙弘, 山田修, 稲尾 雅代

浅井 康文, 安详 博昭, 藤堂 景茂

安倍十三夫, 樫野 隆二, 小松 作蔵

先天性奇形の中で発生頻度が最も高い疾患沁心蔵疾患 であり，出生10万に対し810例の発生を見る，また新生 兄期汇死亡する割合む心蔵疾患が最も多く約 $1 / 4$ を示め ている.

それ故，先天性心臓疾患江対方名外科治療名次第に新 生児期における手術前後の管理が注目される様になって 来ている.

札幌医大胸部外科教室、括いて昭和53年 8 月末日里 でに外科治撩を行った生後 12 力末満乳児先天性心疾 患症例302例について検討した，疾患では心室中隔欠損 症 (VSD) が最む多〈138例，次いでファロー四徴症 (TOF) 38例，動脈管開存症 (PDA) 35例，完全大血管 転位症 (TGA) 26例, 総肺静脈還流異常症 9 例, その他 56例となっている. 乳児早期に死亡する完全大血管転位 定, 総肺静脈還流異常症あるいは大動脈離断症などの症 例が次第に増加しつつある.

開心術症例は補助手段として人工心肺のみを用いた 42 例および体外䛻環併用超低体温法によって行った59例の 計101例である。

手術成績はVSD あるいはファロー四徴症では比較的 良好であるが，TGA に対するマスタード手術あるいは 総肺静脈舆流異常症に対する根治手術は必して良好とは

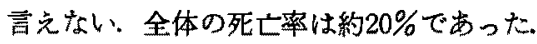

また体外循環併用による超低体温法孔体外循環の進步 により，その適応となる疾患，年龄も限定されて来てい
る. 以上乳児期に心手術を必要とする症例の適応，手術 方法扣よび開心術後の呼吸管理についてる報告した。

\section{III-86. Bochdalek 横暒膜ヘルニアの術後経過}

日本医科大学第 2 病院外科

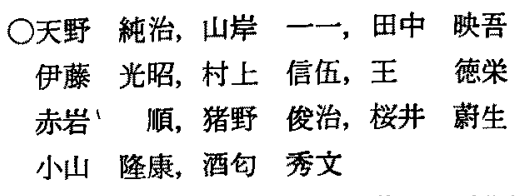

6 例の Bochdalek 横隔膜ヘルニフを経験し, 手術施 行後の 4 例に就て経過を観察し, 毎年, 体重, 身長测 定, 胸部 $\nu$ 線写真, 横隔膜運動, 脯機能測定, 消化管 線検査を行う。

症例 I．生後 12 時間で手術, 欠損孔は $1.5 \mathrm{~cm} \times 1.5 \mathrm{~cm}$, 5 年経過. II. 2 藏で手術，欠損孔は $3.5 \times 5.0 \mathrm{~cm}, 4$ 年経過. III. 10 藏で手術，久椇孔は $3 \times 3.5 \mathrm{~cm}, 10$ 年を 経過. IV. 15歳女性, 久損口 $4 \times 6 \mathrm{~cm}, 2$ 年経過.

経過：新生児例は 2 年目から胸廊の変形を来たし, 著 しい発育障害と肺機能低下あり，3年目に検査で横隔膜 弛緩症之診断，手術せず，現在 5 年目で，肺機能恃幾分 改善. 2 年目で手術施行例は，横隔膜の修復は痕跡を認 めない位，良好で肺機能障害るないが，横隔膜の運動は やや障害され，発育も正常值以下である１0瓷以上で手 術施行例は，手術や，原疾患に上る影響は全くない。

結論 : 新生児死亡例の横隔膜の発育障害は組織所見で も認められない，2歳未满児での本手術施行例では, 発 育障害が見られ，検查で横隔膜運動低下が見られる.特 に新生児期では，久損孔の修復による横隔膜の緊張度が 左横隔膜下動脈，及び神経の不全に連なり，手術時にも 上記の保護に留意すべきである。

したがって，横隔膜欠損の大きさと修復方法，横隔膜 の未熟性が予後を示㗎するすのの一つと考えたい：

III-87. A 型食道閉鎖症における食道延長の 1 経験列 東京女子医科大学第 2 病院外科

市川 辰夫, 今泉了産

先天性食道閉鎖症 long gap 例に対して, 上り生理 的な食道端々吻合を行うべき努力が Howard and Myers の上部食道水銀ブジー法にはじまり，多くの方法が試み られている. 我々の施設においても, long gap の Gross A 型先天性食道閉鎖症に対して上部下部食道ブシー法 を行い, “delayed primary anastomosis” に成功したの で報告する。

症例は生後1 日男児で，呕叶・呼四困難・チフノーゼ をきたし，腹部単純撮影にて胃腸管にガス像を認めず， 
Gross A 型食道閉鎖症と誩断し胃瘻造設術を行っだ.術 中レ線にて下部食道盲端は第 7 胸椎上縁，下部食道甾端 は第 3 胸椎上縁であり，gap は 4 椎体であった. 生後 25 日目よりネラトンカテーテルによる下部食道ブジーを開 始し，7 日目に2 椎体分の延長をみ，一次吻合可能と判 断し, 生後35日目より水銀入りバルーンによる上部食道 惩長街を行った. 生後39日目の透視にて gap は1/2椎体 と一次吻合可能な状態となり，生後51日目に食道端々汤 合術を行った.

下部食道については 1 日 2 回10分間ずつ38回のブジー により2.5椎体分, 上部食道については16日間の水銀プ ジーにより1椎分の延長をみた。下部食道へのネラトン カテーテルの挿入を容易ならしめるため及び十分な力 が盲端にかかる上ら，スタイレットをネラトンに通す工 夫をした。 上部食道水銀ブジーについても、コットンに $30^{\circ} \sim 45^{\circ}$ の傾斜を与えることにより有効な延長效果を办 た、ブシーによる食道延長術は有効な方法であり，容易 に行えるので可及的早期に試みるべきである.

III-88. 先天性食道開鎖应の街後合併应の検討（胃食 道虺流を中心にて）

市立札幌病院第 1 外科

○手戸 一郎, 工藤 正純, 上林 正昭

後藤 洋一, 長谷川正義

我々は過去18例 の先天性食道閉鎖症 (Gross $A$ 型 3 例，C型15例) を経験した. 生存を得ている9 例 (A型 2 例， C型 7 例) の術後合併症について检討する. 特に 讌下困難, 喘鳴、肺炎症状をしばしば綝返すA型 1 例 (Livaditis 法を行った Long gap 例) 及C型 1 例 (Haight

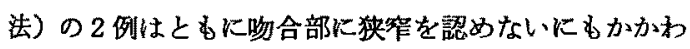
らず食道の通過障害症状を呈するのは本症にみられる下 部食道機能不全（LES 不全）に起因主るものと考える. 胃，食道逆流はあらゆる角度の体位でも起り，特に $45^{\circ}$ 以下では容易に这流は吻合部を越える，又夜間就寝後の 逆流は肺炎を誘発し，A型症例ては逆流性食道炎に上る 消化管出血の為にしばしばコーヒ一残查様の呕昍を繰返 したＡ型症例は吻合部にかなりの祭張がさけられな かったか，C型症例は吻合にさいして全く毉張がなかっ た.

食道内王測定では下部食道の高王帯は短かく，それに 続く食道及吻合部への5つク明瞭でなく，上部食道の 高王带がほぼ正常にみとめられることにより，本症に特 有な LES の機能不全と過伸展による食道機能の低下を 示すりのであった
治㞠奶策は体位を良好に保持する様につとめること， Bethanechol 使用, Fundoplication 等かiすすめられてい るが，我々の症例は体位保持の Infant seat の使用及び Pyloroplastyで良好な結果を得ている.

\section{座長のまとめ}

沢口 重徳

III-84（慈恵医大第 1 外科山崎洋次他）は過去 11 年間 に経験した15蒜以下の頚部疾患275例の臨休統計を報告 した。外科的甲状腺疾患症例が少いこと，リンパ節を主 とした炎症性疾患症例が圧倒的多数を占めること, 先天 性敦胞ないし腫場が少くないことが，成人に比して小児 では特徴的であった，結核性りン八節炎 5 例は多いと思 われたが，必ずしも全例が病理組織学的ないし細菌学的 に確認された訳ではないといら。

III-85（札蜆大胸部外科安喰弘他）は生後12力月以 下の先天性心疾患312例の臨床統計を報告したVVSD 138例, TOF 38例, TGA 36例, PDA 35例, その他65例 であったがこえらの中には心疾患以外の一般外科疾患 (胸腹部内葳奇形)の合併はみられなかったという。開 心術症例は体外循環42例，体外循環併用低体温59例であ り，乳児期における根治手術の適応，手術方法, 術後呼 吸管理にる言及したが，いずれる詳述は不可能であっ た. 早期新生児期に敊ける診断法の進步が，小児一般外 科の立昜から切に望まれる.

III-86（日本医科大学第二病院外科天野純治他）は Bochdalek $ヘ ル=ア 4$ 例 (手術時年龄: 生後12時間，2 藏，10紫，15歳）の術後経過を検討して 2 例に横隔膜弛 緩、運動制限と発育障害を認め, 手術時に横隔神経と血 管を損伤しないよろに注意すべきことを強調した。討論 (㮌天堂大学小児外科平井)で指摘されたように，著な 症状を呈する横隔膜弛緩症が経過観察されているが，こ れは手術治療が積極的に行われるべきであると考える.

III-87 (東京女子医科大学第二病院外科市川辰夫他) は食道閉鎖 Gross A 型症例に対し，上下両盲端の延長 術を行い，生啳59日食道端々昒合を施行しえた1例を報 告した。 long gap 症例に対しては, この Howard 法の 他に, Rehbein 法や Livaditis 法などが行われている が，食道を自然の状態で吻合することが理想的である.

しかし，Howard 法により延長されない症例があるので 無理をしないことや，これに伴い易い合併症があるので 注意することが大切である。

III-88（古立柇幌病院第 1 外科手戸一郎他）は食道閉 鎖18例中 9 例の生存例について術後合併症を検討し，哄 
下困難，喘鳴，肺炎症状を繰返す 2 例を報告した。これ ら怯 Livaditis 法施行 A 型症例と Haight 法施行 C 型症 例であり，吻合部狭窄がないのに食道通過障害と食道下 部樌門移行部逆流を呈したが，体位を半坐位に保持する ことと四門形成術施行に上り治瘦した，本症術後合併症 の病態解明と予後改善に資する報告であると考える。

\section{小児・腹部 I（III-89 94）座長 木村 茂}

III-89. 先天性幽門閉鎖应の 1 治塗例 北摄病院外科

篮川 脩，西代 博之，加藤 佳典 大阪医科大学一般消化器外科 木田 宏之

先天性消化管閉鎖症は稀な疾患であるが，幽門閉鎖症 の発生は更㲹少い。新生児期に本症と㟝断され手術が行 われた症例は自験例を含めて54例（国外38例，国内16 例）が報告されているにすざない，

幽門閉鎖定は，囜門部あるいは近接前庭部とおける消 化管壁の断絶または膜様隔壁による閉鎖を意味するが， 文献では膜様閉鎖の頻度がたかく，女児にやや多く，胎 生期の上部消化管閉塞の結果としての羊水過多症がみら れることが多く，概して生啳数日のらちに膜切除・幽門 形成あるいは胃腸吻合が行われているが，衍後生存率は 約70\%である。

自験例は, 満期・正常分婏, 生下時体重 3,600g の女 睍で，妊㖘経過中に羊水過多症を認めている，生後 2 日 目，授乳開始時より胆汁を混じない呕吐が持続し，体重 減少，脱水が著明となり4日目に来院. 膜部に膨隆や腫 瘤を認めなかったが，上線撮影で胃泡以外消化管内の gas 像を全く認めず，造影剂も胃が充盈されるのみで十 二指腸への移行はみられず, 頻回の無胆汁性呕吐の症状 とこれらレ線撮影所見から本症之訩断，全身状態を改善 したろ兄生後 6 日目に開腹. 胃十二指腸の速続性は, 視 診では正常にみえたが，幽門部の触診と胃切開による内 腔の所見により索状結合織性の消化管壁断絶が確かめら れ，索状部分を切除して胃十二指腸端々吻合と胃瘦造設 を行った. 幽門部以外の腹部藏器に異常所見はなく，切 除部分の組織所見は結合組織と平滑筋組織で，幽門の構 造は認められなかった，閉鎖形態は Gerber の分類の I B 型であった，術後，胃䕜上り内容を吸引し，経静脈 栄翊を行ない，造影剤の吻合部通過を確かめたのち術後 7 日目に経口恸取を開始した，術後経過は良好で発育は 順調である。

自験例の概要に文献的考察を加え報告した.

III-90．急性鿓血を呈した新生児胃奇形腫の1例
君津中央病院小児外科

$$
\begin{aligned}
\text { O松清 } & \text { 央, 緒方 創 } \\
\text { 同小児科 神田 } & \text { 勝夫 } \\
\text { 同病理 } & \text { 高沢 博 }
\end{aligned}
$$

新生児胃奇形稙は発生部位が稀で，本邦でる報告例は 少い，本例は生下時より腹部膨隆，チフノーゼを主訴と した症例で, 腹部単純レ線像，経静脈堅孟造影，超音波 検查等にて奇形腫と晾断したが，急速な貧血出現，腹部 膨隆にて全身状態悪化し，生啳46時間目に緊急手術を施 行した．開腹所見では腫瘤の被膜が破れ，腹腔内への出 血が双られた。腫瘤は胃小弯側後壁より発生したすので, 病理組織所見では各々胎児性を示す 3 肧葉性の各種の組 織成分が混在して打り，小児恶性腫場研究会の分類に従 い未熟奇形盾とした．術後筫血が続き，鉄・Vitamin $\mathrm{B}_{12}$ 合珴投与と輸血により約半年で正常化し，以後順謂 に発育している. 小児胃奇形連は本邦で我ヶが調べ得た むのは11例と少く，更に新生児例は 2 例のみである. 我々の症例が生後46時間で開腹手術した原因として分婏 障害による出血が考えられる。新生児死亡の約 $10 \%$ は分 婏障害に起因し, 又外科系管理の必要な障害る全出生の $2 \sim 3 \%$ になる. 障害内容は頭部損傷, 鎖骨骨折, 四肢

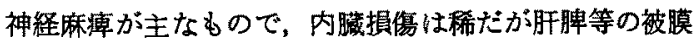
下血腫破裂の報告もあり，我々の症例も産道障害による 腫溜損傷例 と考克られる. 又術後貧血の持続について は，その原因として胃性䆩血が考えられ，今後良性連瘍 摘出に関し出来るだけ切除範囲を少くすべきであると考 光る。

III-91. 空腸准造設, 高カロリー輸液施行 2 週間後に 再開腹した広范な壊死性腸炎の新生児例

東京女子医科大学第 2 病院外科

今泉了彦, 市川 辰夫

14日女児. 主訴は呕吐, 腹满, 下血. 既往歷には特記 すべきことなく，生下時体重 3,060g. 仮死，RDS，䏴静 脈へのカテーテル拝入等はなかった，生後10日目夕刻突 然胆汁性呕吐で発症し，次第に頻回となり腹満む出現. 13日目呼吸困難から心停止をきたし蘇生術にて回復して いる．術前白血球减少，血小板减少があり，代謝性フチ ドージスを示した，血液培羕陰性：2月 6 日，開腹する と Treiz から $20 \mathrm{~cm}$ 以下の小腸か広範に堎死に陥り, 所々に穿孔寸前を思わせたが，高位空腸に 2 連鍷式腸瘦 を扮き，腹䐁減圧と中心静脈栄羡で管理した２週後の 再開腹時には肉眼的に濖死所見はなく，小穿孔によると 思われる強度の癒着部分と腸㿉閉鎖を含め小腸部分切除 
で終った.

その時点では，従来予後の極めて悪いとされる広範な 㗄死性腸炎に対し，2期的飞手術することにより小腸部 分切除で斉んたこことに大い満足していた。

しかしながら経口摄取開始後の下浰之栄盖吸収不全忙 深刻で, 便培羔では多剂耐性の Klebsiella 菌が常に険 出され，乳糖不耐，ブドー糖不耐，ミルクフレルギーが みられた，経口投与を断念し中心静脈栄荃に切換克た が，5月下旬再び腹満，呕吐が出現し6月1日再々開腹

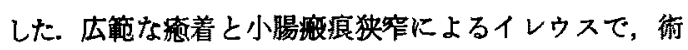
後肺合併症，DIC を併発，初回手術より127日目に死亡 した

不幸にして本症は失ったか，渴管の完全減压に上り本 症の進行はある程度阻止できたと考えており，本症にお いても早期発見, 絶食, 胃管等による吸引減圧の早期処 置により本症の予後はまだ向上するものと考えている。

III-92. 特異な発症を示した小児回晹重複症の 2 例 賛育会病院外科

落合 治海，垣花 昌彦，熊本 基 独協医科大学第 1 外科

長島 金二, 横田 勝正

消化管重複症は稀な疾患とされていたが，最近小児外 科の発達上共にその報告が增加している. 我々も今迄6 例の消化管重複症を経験しているか，今回穿孔及び出血 により症状を呈した 2 症例を報告する.

症例 1.6 歳男子, 呕気呕吐を伴う腹痛古り, 翌日右

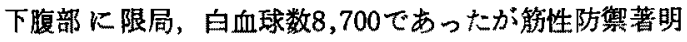
なため，急性虫垂炎の診断で救急手術を行なった。

手衡所見：回腸末端から $10 \mathrm{~cm}$ 口側の反腸間膜側に拇 指頭大の原瘤があり，これの穿孔による限局性腹膜炎で 市った。腸切除，端々吻合施行す，病理組織所見ではび らん，潰瘍を伴う小腸粘膜に内腔を覆れた回腸重複症.

症例 2. 1 歳 5 力月男子, 下尉呕吐を主訴として入 院. 呕吐軽快せず，腹部単純 $\mathrm{X}$ 線所見では麻瘃性腸閉塞 像て浣腸により軽快したが，2 日後再び呕吐あり，腹部 単純レ線写真て鏡面像著明，腸閉塞の診断で救急手術施 行，手術所見では回腸末端より口側 $40 \mathrm{~cm}$ の反腸間膜側 に $10 \mathrm{~cm}$ に亘る血性震腫を認め，それによる腸閉塞で あった，回腸切除，端々伆合施行．病理組織所見では， 異所性胃粘膜, 脺, 溃湯等を伴わない粘膜下出血がみら れた回腸重複症であった。

考案：本邦報告約100例をみる. 症例 1 の様な重複腸
管穿孔による急性腹症を来した症例は1 例で，術前虫垂 炎之詥断されたものが 2 例を数学るのみである．又症例 2 の如く, 重複腸管粘膜下出血により腸閉塞を起した症 例は見当らなかった

以上我ムの経験した症例を述べ，嗝断につき若千の文 献的検討を加之た。

\section{III-93. 消化管重複症の 2 列}

埼玉医科大学第 2 外科

○森田 孝夫, 福本 守男, 小林 雅朗 藤岡 正志, 端山 俊晃, 里見 昭 時松 秀治, 石田 清

消化管重複症は症状の多彩さ，臸断の困難さなど種々 の点で興味をるたれる消化管の先天性形成異常である. 我々は本症の小児例 2 例を経験したので報告するととる 飞，過去 5 年間（1973年 1 月～1977年12月）の本邦報告 症例46例について, 主に猃断, 臨床症状及び病理学的所 見について若干の検討を行った，症例 1.8カ月女児. 回腸末端の隼胞状重複症で腸重積の原因となった（既発 表)，症例 2. 2 藏 8 力月男呪. 急性蛙炎の症状を呈 し手術に上り，結腸重複症（真胞状）が認められた， 2 例とむ腸切除を行ない，術後経過は良好であった。われ われが集計した消化管重複症の臨床症状は小児では悪 心，呕昍が約78\%にみられた，年龄では39例中，乳児期 14例，幼児期10例であった。発生部位では回腸が約54 \%を占め，次いで大陽，十二指腸の順であった，形状で は，球状型約74\%，管状型約 $26 \%$ であり，消化管と交通 のあるものは管状型約58\%，球状型約 9\%であった。

日常の喰療に際しイレウスや虫垂炎の如きありられた 疾患の症状を示す患者の中にも，消化管重複症があるこ とを念頍におき，適切な治療を行ならべきであるらと考 克る.

III-94、重複腸管の異所性算粘莫に由来せる 回得溃化 性潰璂の 1 穿孔例 東京都立豊島病院外科

$$
\begin{aligned}
& \text { 井上 勇, 川越 常盤 } \\
& \text { 森 正穗, 上垣 恵二 }
\end{aligned}
$$$$
\text { 同病理 中村 俊彦 }
$$

過去 6 年間（1973〜1978）に経験した15歳未満児の穿 孔珄腹膜资は新生児 7 例（胃穿孔及び破裂 4 , 胎便性腹 膜炎 2 ，回腸多発穿孔 1$)$ ，回腸第孔 (3M)，特発性胆 道破裂 (2Y)，十二指晹溃瘍穿孔 (4Y)，メッヶル憩室 穿孔（6Y）の各 1 例，外傷性腹膜炎 6 例，虫垂炎穿孔 10例の総計27例であるか，最近重複腸管の異所性胃粘膜 
に起因した回腸消化性濽浧穿孔の與味ある1例を程験し た，症例は14歳女児で，メッケル腮室牚孔の疑で開腹さ れたが，回充弁より $170 \mathrm{~cm}$ 口側回腸の穿孔で，同部間 膜側に超手拳大劉腫様 1 側交通性管状型の重複腸管を認 めた．組稢学的に重複腸管内腔は全て胃粘膜で，入口部 の周辺に帯状の少数の幽門腺がみられた以外, 全て分化 度の高い胃底腺が占めていた。濽痬は $5 \times 1.5 \mathrm{~cm}$ で回

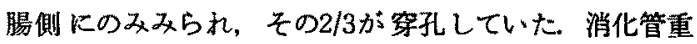
複症180数例の集計中，粘膜性状の記載がある120例に拉 いて異所性胃粘莫が和られたすのは14例（11\%）であ り，その発生率は欧米のそれに比し可成り低い，小腸に 発生した duplication with ectopic gastric mucosa は 12例であるが，そのうち 7 例は幽門腺のみから成り，胃 底腺を認めたものは 5 例である. 又内腔が全て胃粘膜で あったものは島津のI例を数えるのみである.穿孔性腹 膜炎を呈した 4 例は全て管状型交通性で胃底腺を有し， 比較的高龄で手術されているが，我々の症例以外は重複 腸管自体の穿孔であり，回腸側に消化性潰瘍を諗めてい tsw.

石田，平石例には回腸側に消化性溃瘍が汉られるが， いづれも球状型，幽門腺型であった，一般に重複腸管の 約20\%は異所性胃粘膜を有するといわれているか，本邦 の集計では更に低いと思われ，又その合併症である潰瘍 の出血, 穿孔例も極めて少ない. 重複腸管内胿全てか;胃 粘膜で胃底腺優位, かつ回晹側に消化性潰湯を発生し, 穿孔性腹膜炎を呈した我々の症例に類似した症例の報告 は見当らない.

\section{座長のまとめ 木村 茂}

III一89〜94の発表は比較的稀な小児腹部疾患の症例報 告である.

III-89（北提病院，笠川）は生後6日に手術を行った 幽門索状閉鎖例を報告, 術前腹部単純し線写真と胃造影 より診断している. 索状開鎖部の組織を報告している. 胃の支配動脈には異常無かったと質問に答えている，本 邦での報告は16例であるとの事であるが，最近は本症の 存在が認識されているためか，術前に確詅がついている ことが多いよらである。

III-90 (君津中央病院, 松清) は生後46時間に下血の ため緊急手術を行った胃奇形腫の 1 治験例の報告であ る. 術前レ線㭘查，超音波検査より奇形厘の猃断は得ら れたが，発生部位の確定診断は得られていなかった。 胃 小驾後暨よりの発生で，隀瘍とともに胃部分切除が行わ
れている. 組織学的には未熟奇形腫で悪性所見は琹めら れなかった，一般に小児の胃奇形尰では悪性を示主例が 殆どないので，胃の切除範囲はなるべくさいのがよ い.この例む男児であるが，日本の小児胃奇形腫の報告 例が全て男児であるのる興味深い。

III-91（東京女子医大，今泉）は生後14日炕手術を行 った小腸の広範囲にわたる壊死性腸炎の報告である．初 回は健常な空腸上部に腸㾇を造り，ついで2 週後に再開 腹したところ，広汎な小腸㙍死部は回復しており，小箸

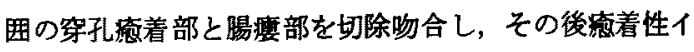
レウスのため 3 月後死亡している. 臨床経過が壊死性腸 炎の回復過程を考える上で興味深く，また術後管理とく に栄着管理上，多くの問題を提起した例である.

III-92（替育会病院，落合）, II-93（埼玉医大 2 外, 森田) 特よび正一94（豊島病院, 井上)はいつれす消化 管重複症（回腸 4, 盲腸 1) の発表で, 合併症として穿 孔、粘膜下出血による腸閉塞, 腸重積, 炎症, 重複腸管 部の異所性胃粘膜飞よる隣接腸管の消化性潰湯が報告さ れた．本症の報告はかなり多くなって和り，小児の急性 腹症に際し念頭におくべき疾患である．ただ術前には消 化管重複と確詥するための決め手となる検查法がないだ けにむつかしいことも多い：たた異所性胃粘膜が存在し ておれば， ${ }^{99} \mathrm{Tc}$ とよるシンチグラムが有用となるが， メッケル愁室と鑑別しなければならない，本症がそれ程 稀なむのでなく，小児急性腹症に際し考慮すべき」つの 疾患であることを銘記すべきであろう。

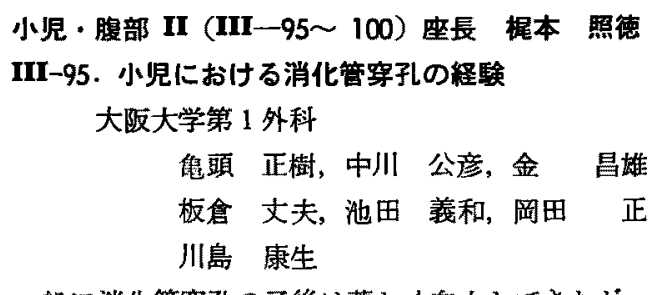
一般に消化管穿孔の尒後は藷しく向上してきたが，小 児特に新生児期，乳児期初期のそれは小児に特有の疾患 によるものが多く，その死亡率もまた高い、今回我々は 昭和37年より本年 8 月迄の間に教室に秃いて経験した新 生児期，乳児期初期の消化管穿孔の29例につ検討を行 った.

穿孔部位は，胃16例 (生存 6 例)，小腸 12 例 (生存 5 例), 結腸 1 例 (生存 0 ), 計29例 (生存11例) であ。 大. 疾患別に恃，新生児胃破裂15例，十二指腸閉鎖合併 胃穿孔 1 例，塙死性 腸炎 5 例，腸閉鎖合併 小腸穿孔 2 例，ヒルシニスプルング病合併結腸穿孔 1 例，また手街 
後合併症として5例であった。

胃破裂又は穿孔は16例で，来院時日啫は1日〜8日， 男女比は男 10 ，女 6 ，生下時体重は $1,350 \mathrm{~g} \sim 3,800 \mathrm{~g}$, 平 均 $2,737 \mathrm{~g}$, 穿孔部位は大弯側に多く見られた，生存率で みると ICU 開設前後で $12.5 \%$ から62.5\%と著しく改善 された.

次に腸穿孔の应例は13例であった。墩死性晹炎の 5 例 は術前にレ線上特徽的な所見は得られず，開腹時に確定 診断された，多発穿孔が3例に見られ，手術法は口側の 小腸掼が主に用いられた。 下部腸管の通過障害を伴った 晹穿孔の尒後は要かった。

全体では，発症より手術までの時間上予後は，早期発 見手街例に良い傾向があった．細菌学的検查ではグラム 陰性罩菌が多かった. Endotoxin によると思われるDIC 様症状を呈し，一パッン療法を行った 5 例中生存は 3 例 でらち 2 例を提示した.

小思の消化管穿孔は最近の本邦報告でも生存率 $22 \sim 67$ \%と満足できるものではないが，術前からの政重な管 理, 腹膜炎, DIC 等に対する積極的な治療により一層 改善ざれつつあると考えられた。

\section{III-96. Meckel 賏室合併症の 4 例}

下ヨ夕病院外科牧原 良行, 安藤 重満 名古屋保健得生大学外科

$$
\text { 伊藤 寛, 山口 茂 }
$$

私共は，最近 Meckel 唕室に起因する合併症の4例 を経験した。

症例 1 . 3 歳男児. 反復せる大量下血のため開腹する

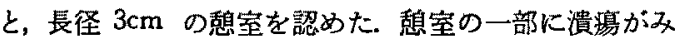
られたが，異所性胃粘膜はみられなかった。

症例 2. 生後 2 日目よた呕吐が持続し，腸閉塞症状 を旺した女児で, 生後 3 日目に入院. 腹部には Hernia into the umbilical cord が存在しており,ヘルニアの内

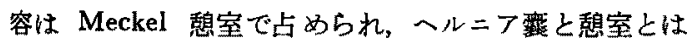
全面に線維性瘾着が認められた。この症例では, 憩室に より回腸が率引・屈曲され，腸閉塞の原因となってい た.

症例 3.1歳女児. 下血と呕吐を主訴として入院. 憩 室に異所性胃粘膜が存在し, 䚋室先端部の潰癔が穿孔

し，腹膜炎をきたした。

症例 4.13歳男児. 腸閉塞症状を主訴に来院. Meckel 䕀室先端 と腸間膜の間に長さ $2 \mathrm{~cm}$ の比較的太い血流 に富えだ vitelline artery が存在し、このため䅣室が Bridge を形成し，ここへ腸管があくり込み，晹閉塞症
を呈した。

以上 4 例にみられるよらに, Meckel 憩室に起因する 合併症は，出血，腸閉塞症，想室炎，穿孔と多彩な臨床 像を示し，㹂急手術を要することが多く，術前馀断は困 難である．また症例 $2 ， 3$ にみらるように、発生学的 に興味する所見を呈していることが多く，手術の際に充 分な観察が必要と考えられる。

これらの症例に若干の文献的考察を加えて報告した.

III-97. 器質的原因を有する小児腸重皘症の6 治験例 岡山赤十字病院外科

大塚 康吉, 国方 永治, 宇賀 五郎 住友別子病院外科 加地 信产

われわれは過去 7 年間に176例の小児騔重䅡症を経駺 したが，そのうちの31例に手術を行い，6 例に原因と思 われる器啠的病変を認めた。

症例 1. 7 力月, 男児. 3 週間前に腸重積の整復をら けている，開腹して整復するに，回腸末端部に腫瘤を 触れたので摘出した，病理組織晾断は adenomyoma で あった。

症例 2.1歳11カ月，男児．開腹して整復するに，虫 垂根部に近く隀瘤を解れたので，盲腸切開してポリーブ を摘出した，病理組織診断は若年性ポリープであった。

症例 3.1歳 1 力月, 女児 1 力月以内に 3 回, 腸重 積の整復をらけている. 開腹するに回盲弁より $70 \mathrm{~cm} の$ 部に回晹回腸重積があり, 整復すると腫瘤を触れた。こ の部を切除すると有茥性ポリープがあり，病理組織診断 は若年性ポリープであった。

症例 4.10力月，男児. 注腸するに回腸回腸重積が整 復できず手術した，回盲弁より $20 \mathrm{~cm}$ の部の回晹回腸重 皘を整復したが，腫瘤を触九，腸壁の循環障害があるの で腸切除した，病理組織診断は lymphoid hyperplasia で あった。

症例 5. 8 歳, 女児, 11 力月， 4 歳， 6 歳の 3 回, 腸 重積の整復をらけている. 注腸で回腸回腸重積が整復で きず手術した，回盲并より $25 \mathrm{~cm}$ の部に尰瘤を触れたの で切除した，病理組織䛦断は迷入莝であった。

症例 6.1歳 3 カ月, 男皃. 1 遇間前に腸重積の整復 をらける.開腹すると回盲弁より $40 \mathrm{~cm}$ の部にメッケル

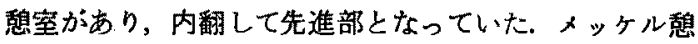
室を切除したが一部に畽瘤を触九，病理組織学的に迷入 腈之䛦断された。

小児晹重積症の原因としては回腸 adenomyoma は本 邦では 2 例の報告があり，盲腸の若年性ポリープは 1 例 
あるのみで，回腸の若年性ポリープはこれまで報告はみ られない。

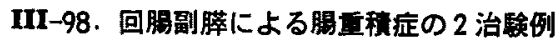 防衛医科大学校第 1 外科}

溝口 修身, 初瀬一夫, 黑川 胤臣 平出 星夫, 三村 一夫, 岩佐 博 同小児科 賀川 倫子 同第 2 病理 布施 裕補

保会棇合病院外科 寺島 㹂

乳幼児急性腹症として腸重積症は重要な疾患の一つで ある.最近我々は回腸末端部に迷入した副脺を先端とし た 2 例の腸重積症を経験し，共に手術的に救命し得たの で報告する．症例 1 は 5 力月女児. 来院14日前より呕 吐，腹部膨隆および血便を伴い，当院を受診．注腸にて 寛解せず，直ちに開腹術を施行した．回盲部より $25 \mathrm{~cm}$ 肛門側に亘る回腸・回腸・結腸型の腸重皘症で，その回 腸先端部に小穿孔と小指頭大腫瘤を認めた，この腫瘤は Heinrich II 型の副脺であった。

症例 2 は 3 歳 4 力月男児. 来院 3 日前より呕吐, 腹 痛，左側腹部腫瘤および血便を訴兄，当院を受診．注腸 にて寛解せず救急手術を施行した．回盲部より $43 \mathrm{~cm}$ 口 側から $23 \mathrm{~cm}$ 肛門側に亘る回腸 - 回腸型の腸重積症で, その回腸先端部に小指頭大腫瘤を認めた。この瘇瘤は Heinrich II 型の副膵であった. 本邦で副膵に起因した 腸重積症は，文献上32例であるが，我々の経験した 2 例 を報告した。

III-99. 小肾腸重積症の臨床的検討一手術適応決定へ の一考察—

\section{熊本赤十字病院外科}

秋山 泰広，松金 秀啺，武内 由典 坂本不出夫, 片㨽茂

小児腸重積症は，比較的一般的な小児救急疾患の1つ であり，小児外科の対象疾患として以前より重視されて いる. 本症の治療は，原則的には，非観血的整復を試み るべきであるとする意見が多いが，手術適応の基準之な るとまちまちである，そこで私達は今回，自験例につい て手乘適応の基準について搝討したので報告した。

私達は, 昭和50年 5 月から，本年 4 月迄の 3 年間に， 本症を再発 5 例を含む68例を経験した，男児43例，女児 25例であった。

年龄別注，生後1カ月から 6 歳迄に及び，4 月か 510カ月の間で37例，54\%をみている.

私達の経験した68例の治療法は，非手術例59例，86.8
$\%$ ，手術例 9 例， $13.2 \%$ でっった その内訳は，即手術 したもの 3 例，整復不能或は他の原因で手術したもの 5 例，腸穿孔例 1 例であった

経過時間と手術頻度についてみると，12時間以内では 手街例 0 で，24時間になると12例中 2 例，16.7\%，48時 間になると 8 例中 2 例 $25 \%$ に手術し，48時間以上は 5 例 全例に手術を行った。

腹部単純写真に上る腸管内ガス像の検討では，12時間 迄の症例は殆んど正常に近く，24時間内でも，ガスの增 加之鏡面像の形成はさ程強くない４8時間以内のものは 全例，著明ながスの增加と鏡面像がみられた。

経過時間々発熱及び白血球数との検討では手術, 非手 術の間に大差なかった。

以上上り

1. 発症上り48時間以上経過したもの.

2. 腸管内ガス像が著明增加し，鏡面像が多数みら れるむの.

3. 発熱，白血球增多，顏色不良，無欲状颜貌等明ら かに全身状熊の悪いむの。

を手術適応と考え，今後の治療方針としたい．注腸整復 不能例は当然手術適応であるが，年齡の低いるのも無理 な注腸整復はさけるべきであると考光る。

\section{III-100．小坚腸重栍症の治療と遠隔成䋶} 信州大学第 1 外科

清水 公男, 石曾根新八, 清水 幹夫 渡辺 厚, 辻本 和雄, 大町 俊夫 清冯 佑爾, 安名 主, 小林 嵫 林四郎

最近12年間に，信州大学第 1 外科で治療した小児腸重 積症 42 例を対象として，注腸整復法の意羲と限界なとを 検討した.この期間に注腸整復が成功したのは10例で, すべて発症後24時間以内に注腸整復が行われている。一 方，注晹整復が不能で，観血的整復を余儀なくされた症 例哒 例で，その内10例は発症後25時間以上経過してお りまた一部の症例では, 理学的に又はX線検査上, 腸 閉塞や腹膜炎の所見が認められた。この锶血的整復例で の開腹時の整復の難易をみると，23例の回腸結晹型で は，ほとんどが容易に整復できたのに対して，回腸回腸 結晹型では 9 例中 8 例が整復は困難で，その内 3 例で晹 切除を必要とした：遠隔調查を行ったところ，注腸整復 例, 観血的整復例のいずれについても，一部の症例で， 時折整復操作と関連があると思われる腹部症状が認めら れたが、両群の間で有意差はなかったまた再発例は1 
例もなかったが，この遠隔調查後に，4日間に 3 回腸重 積症を起こし，3回目には観血的整復を余儀なくされた 回腸結腸型の腸重積症を経験した.

これらの成績より今後発症後24時間以内の症例では全 身麻酔を併用するなどして，より積極的に注腸整復を実 施すると共に，整復の確認とその後の経過には充分に注 意を厸う必要があり，発症後25時間以上経過していた り，晹閉塞や腹膜炎の所見が㤎められる症例では，高度 な腸管障害が推定され，また回腸回腸結腸型では開腹时 にも用手的な整復が困難である事などを考㦄しつ，手術 時期の䐅延を招かない上らな配慮が大切である。

\section{座長のまとめ}

\section{掍本 照徳}

III-95（亀頭）は，最近16年間の新生児消化管穿孔

（1 例は乳児）27例について検討を加えた，全体でみる と66.7\%が死亡しているか，年代別にみると生存率は向 上してきている.これは DIC，肺合併症の発見と適切 な治療に負らところが大きいと結論した。

III-96 (牧原) は, Meckel 䕀室の外科的合併症を 4 例報告した，腸閉塞 2 ，下血 1 ，腹膜炎 1 であるが，発 生学的に興味のある Hernia into the umbilical cord の 内容物としての Meckel，と mesodiverticular vascular band K基因するイレウスについて特侍しく述べた

II-97（大塚）は，器質的原因をむつ晹重積症 6 例飞 ついて述べた、いずれも開腹してその原因をたしかめて いるか，再発を綝り返したか注踢整復が不能で手術した ものである. 器質病変は, lymphoid hyperplasia, 迷入 膵, メッケル馣室のほかに adenomyoma, 若年性ポリー プなどまれな疾患もみられた，再発を繰返すむのは器質 病変の可能性を年齡の如何を問わず考劣ねばならないこ とを示唆した.

II-98（戡口）は，回腸に迷入した副脺が先進部とな って回腸回腸結腸型および回腸回腸型重積をおこした 2 例を述べた、腸管の副粠は決して珍らしいわのてはない が、これが重積のひきがねとなる場合はかなりまれであ る. 演者は文献から調へ上げ，小坚が成人にくらべ発生 率が高いことを示したが，座長は同じ副脇がなぜ小児の 方により多く重積を起こさせるのであるうかという疑問 を呈した，演者恃，乳幼児では腫瘤に比して腸管沿が㹟 いこと，年龄を增してす腫瘤はそれ汪ど增殖しないこ と, 合併症が成人にくらべて比較的多いことを理由とし て举げた

尰重積の成り立ちについては，現在もなお謎の部分が 非常に多い，III-97の 6 例中，5例は回腸汇器質病变を
有していたか，重皘型は回腸回腸結腸型 5 例，回腸結晹 型 1 例であった．素朴に考光れば，病变が回腸にあれば 回腸回腸型が相応しいと思われるが，なぜ回盲部（升） がそれに関与するのであろらか？

III-99（秋山）は，腸重皘症の手術適応の基淮を68例 の経験をすとに提示した，発症から48時間以上経過した むの，腸管内ガスが増加し鏡面像を及るもの，発熱，白 血球增多，無欲状顔貌など一見して全身状態の悪いむの 括よび低年龄（3カ月以下）の4点を学げたこれ以外 の症例は，当然注腸整復を先ず試みるが，その時全麻下 に行らかどうかについて議論がでた，今泉（東女医大） は，ヶタラール筋注で $90 \%$ 以上の整復率であると追加し た．演者は，フェノハール投与たけげあると述べた。

III-100（清水）は，42例の治療成績を述べた．注腸 整復成功は10例で残る32例は開腹した．1/3は24時間以 上経過しており，23例が回腸結腸型，9例が回腸回腸結 腸型であった．9例のうち 3 例は腸切除が必要であっ た. 遠隔調查です再発なく，軽度の愁訴が一部にみられ る浪か恃良好な成績であった，以上から早期例飞は皘極 的な注腸整復を試みる一方，整復の確認が不十分なむ の，晹管の障害が予想されるるのに対してはすみやかに 手術を考虑すべきことを強調した。

腸重積症の演題は以上であったが，平井（順大）か ら，再発に関して器質的病変に起因する腸重積症と何ら 病変のない場合とでは，再発頻度飞差があろらかといら 質問が出された，晹重積症関係の演者 4 名に質したが， 回答は得られなかった。

この問題ははなはだ重要である，座長はこの点につい と岋多大の関心を笴せて括り，自らの経験の上からの印 象としては器質病変合併例の高率の再発という考え方に 対しては甚た啰疑的である.この点を解明するには調べ 方のフプローチにいくつかの隘路があるが，是非取り組 んでみたいと考えている。

\section{小児・腹部 III（101～106）禹長 池田 恵一}

III-101．小児虫垂资の特異性と診断の注意点につい $\tau$

\section{広島大学第 1 外科 横山 隆, 石井 哲也 古本 福市, 市川 徹}

我々は最近 8 年間に経験した62例の小児中垂炎につい て若干の検討を行ったので報告する．年龄之穿孔の有無 についてみると，5歳以下の症例は17例で，全例に穿孔 を認めた，6歳以上では，穿孔例は17例，38\%であり， 年齢が長ずるにつれて，非穿孔例が增加していた，虫垂 
炎の手術所見についてみると，5歳以下の症例では汎発

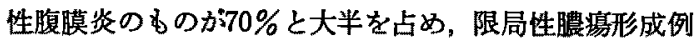
が30\%にすぎなかった，6〜15歳では穿孔例の減少と共 K，穿孔例でも，限局性膿煬形成例が增加していた，初 発症状についてみると，5歳以下の症例で性腹部症状の 発現頻度が少く，発热を初発症状とするものが30\%にみ られた。 6 歳以上の症例では, ほぼ全例が腹痛を初発症 状としていた. 発症後, 初診した医阨の診断名を検討す ると，5歳以下では24時間以内に虫垂炎の診断をらけた 症例はなく，多くは上気道感染，自家中毒として加療を

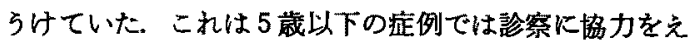
られぬ事，腹部所見がつかみにくい事に基因すると考え られた，6〜15藏の症例で性特に非穿孔例では早期から 虫垂炎の診断を受けていた，発症から来院迄の時間も幼 少になる程，晕い傾向があり，特に限局化したるのは 2 日以上経過して来院するるのが多くみられた．腹部所見 では奻少になる程, 腹壁緊張, 氐痛, Blumberg's sign 等 がつかみにく、傾向が双られた．X線新見では，非穿孔 例でも小腸がスの異常, 腸腰筋陰影の消失, 腰椎の側弯 等が半数以上に認められ，注目すべき所見であった．白 血球数は診断上，特に有用ではなく，むしろ，好中球增 多が多くの症例に認められた，注腸レ線所見は malrotationの虫垂炎症例 1 例について行ったか，猃断上有用 であった。ささらに慎重に症例を重ねて検討しなければな らないと考える.

以上，我↔の経験した62例の小児虫垂炎について検討 した結果を報告した。

III-102. 最近11年間に於ける小児虫垂炎の統計的観 察，特に6才児以下23例を中心として

国立千葉病院外科

○山城 敏行, 伊藤 力, 堀部 治男 传々木徳秀, 田沢 洋一, 後町 千秋

福田 说夫

最近 11 年間の虫垂炎手術例は782例，5ち15歳以下の 小児虫垂炎は173例，22\%，6歳以下は 31 例，4\%で， 内わけは男児20例, 女児 11 例, 最年少例は 1 歳 9 力月女 児である. このうち病歴の記載の明確な23例につき， Kazarian らに従い4 群に分類し検討した.

正常虫垂古るいは軽度の病理所見のI 群 1 例，急性化

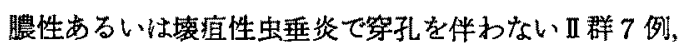
穿孔して限局性腹膜炎あるいは膿演を形成している开群 13例，沉発泩腹膜炎のIV群 2 例である. 穿孔率は65\%で ある。
病型と年齢の間に明確な関係はみられない。48時間以 内の手術例の穿孔率 $40 \%$ に対し，48時間以後のすのでは $85 \%$ となっている。 24時間以内の手術例は I 群 1 例, II 群 4 例，正群 2 例である.

腹部所見では，王痛は全例飞認める。腹壁緊張ないし ブルンベルグ改候陽性は，II 群 $86 \%$ ，II，IV群93\%であ り，手術適応の根拠となっている.

術後死亡はIV群 1 例 5 藏児で, 術後30時間で循環不全

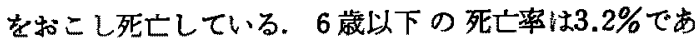
る.

術後合併症としては，創感染が多く，穿孔群の27\%に みられている。

腹腔内ドレーン留置との関係はみられない，腹腔内遗 残膿瘍は, 第孔群の13\%にみられている。

これらの術後合併症恃，穿孔群にのみみられ，重篤な 結果をまねく場合もあり，穿孔以前の手術が望まれる。

そのためには疑いがあれば入院させ，腹部所見をみの がさない上う，くり返く镅察することが必要である.

III-103. 小児虫垂炎の術後感染と抗生剂缁法 千葉大学小児外科

若山 芳彦, 飯田 秀治, 川村 健児

大川治夫，真家 雅应，横山宏 高穚 英世

小児蜞炎の診断はしばしば困難であり，また容易に 穿孔を抗こす為, 術後の合併症す高率に発生する.今 回, 過去10年間の小児虫垂炎112例を対象とし，街後感 染を腹腔内検出菌とその薬剂感受性並びに使用抗生剂よ り検討したので報告する.

虫垂奖の内訳はカタル性26例，蜂简織炎性16例，壊庢 性21例，穿孔性49例である。穿孔性虫垂炎仕 1 歳から 5 歳では60\%，6藏から10歳で $49 \% ， 11$ 歳以上では $24 \%$ であった，術後感染は塄疽性及び穿孔性虫垂炎術後にの みみられ，穿孔性蛙资では63.6\%に術後㓣感染又は遭 残膿煬が認められた。

術後感染の発生率を前半 5 年, 後半 5 年にわけ比較し たところ，創感染・遗残腰演ともに後半 5 年間の方が約 3倍增加していた，使用抗生肪では，C.P.か338\%から8 \%と著明に減少していたのが興味深い、腹腔内検出菌を みると, 好気性菌では大腸菌が最も多く40例中27例に検 出され,ついで粶朖菌, 肺炎桿菌の順であった。様気性菌 では無芽胞グラム陰性桿菌の Bacteroides fragilis が22例 に検出され，昭和52年では約 $90 \%$ の症例に検出された 検出菌の薬剂感受性をみると好気性グラム陰性桿菌に 
対しては Aminoglycoside 系抗生郕方高い感受性を示 したが, Bacteroides fragilis に対しては C.P., LCM, CLDM だけが高い感受性を示した. 術後合併症と使用 抗生風の適否を梌討したところ，適合抗生剂使用 7 例で は合併症は 2 例のみで，不適合抗生剂使用17例では合併 症か15例にみられた。

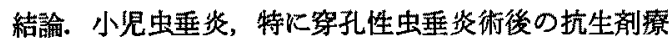
法は, 好気性グラム陰性桿菌に対する Aminoglycoside と嫌気性菌 Bacteroides fragilis に対する LCM あるい は CLDM との併用療法が最適であると考点る。

III-104. 腸㕠を伴なった Hernia into the umbilical cord $\sigma 1$ 治験例

静岡県, 溙原総合病院外科

$$
\begin{array}{r}
\text { ○竹村 和郎, 丸山 洋 } \\
\text { 酒井忠, 中村 孝哉 }
\end{array}
$$

最近, 私共は Hernia into the umbilical cord の症例 で、ヘルニア衰の一部に腸瘦を伴なった 1 例を経験した ので，報告した

症例は生後 I 日目の男児. 在胎40週，正常分婏, 生下 時体重 2,510g. 羊水過多なく，混濁も軽度であった、 $ル ニ フ$ 整は $4 \times 4 \mathrm{~cm}$ の pediculate form で, 基部の直径 $2.5 \mathrm{~cm}$. 脐带は震の頭側右方に付着，その尾側左方で腸 管粘膜が外彩，先端から胎便の排出が認められた。なお 胎便の排出は経肛門的にも認められた，腸瘦を伴なった Hernia into the umbilical cord 上鈴断し, 生後10時間で 手術を施行した.

膀輪に沿って皮切を加光開腹. 脱出藏器は腸瘘形成部 前後の小腸のみで, 腸瘦形成部は回腸末端部より $18 \mathrm{~cm}$ の部位にあり，この部の小腸が悡室状に突出，先端がー

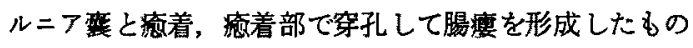
と判明した、な挆他の腸管合併病变は認められなかっ

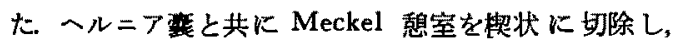
腹壁は一次的に繾合閉鎖した，街後経過良好で，現在正 常に発育している.

Hernia into the umbilical cord は，腸管の腹脉内還納 障害により生ずると考えられ，小腸自体の合併病変が多 いことが特徽の1つとして挙げられている.しかし本証 例の如く，腸瘦を伴なった症例は比較的稀なるのと考え られる. 本症例の発生病理学的背景を推測すると, 䏴輪 による絞拒のための血行障害が原因となって，Meckel 敗室先端に癒着, 穿孔を来たしたものと考兄られた。

III-105. Wiedemann-Beckwith 应候群の 1 例と 本邦報告例の検討
東邦大学第 2 外科 久保田和博

Wiedemann-Beckwith 症候群は胳部異常，巨舌，巨大 児を 3 主徵とする症候群で，現在までの本邦報告例は， 24例にすぎない，今回我々は，一般状態不良で生後10日 で死亡した Wiedemann-Beckwith 症候群を経験したの で, 剖検所見と文献的考察を加兄報告する.

症例恃，日龄 0 日の男児，脂へルニアを主訴として入

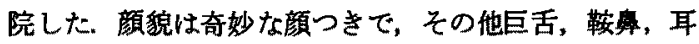
梁奇型, 短頭があり, 検査所見では, 多血症, 低血糖を 認めた．腹部に直径約 $8 \mathrm{~cm}$, 皮フ面より約 $7 \mathrm{~cm}$ 隆起した 䐗带へルニアを認めたので手術にて一次的に閉鎖した。 術後両下肢の循環障害を軽度認めたが，24時間後に消失 した．血糖は入院時 $15 \mathrm{mg} / \mathrm{dl}$ であったが輸液開始後70〜 $80 \mathrm{mg} / \mathrm{dl}$ を維持した. 内分泌学的検查では, 成長ホルモ ンは $80 \mathrm{mg} / \mathrm{dl}$ ，甲状腺刺激ホルモンは $121 \mu / \mathrm{ml}$ と高值を 示し, $T_{3}, T_{4}$, insulin, 血中11-OHCS は正常であった。 日齢 3 日頃より黄疸が出現し，6日目血清ビリルビンは $17 \mathrm{mg} / \mathrm{dl}$ まで上昇した．9日目より全身状態が悪化し， 日齔10日目に死亡した。

本邦報告例は，1970年坂本らの報告を始めとし，本症 例を含め25例の報告例を見る. このうち，男児15例，女 児 7 例，不明 1 例にて男児に約倍の発症を見た．発症原 因等については，いまだ諸家の一致した報告を見ない．

\section{III-106. 血管撮影にて流入血管を認めた新生児卵金} 膘の 1 例

\section{都立大塚病院外科}

堀博之, 饭塚一郎, 渡辺 五朗 化科 孝子, 中野 正高, 阿部 秀一

同小児科 井上和子, 森清

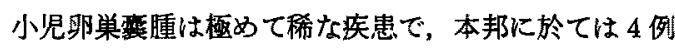
報告されているにすぎない，我々は，出生直後腹部腫瘤 を発見し，血管撮影で卵巣雃腫と臸断し治療を行った一 例を経験した，症例は $3,780 \mathrm{gr}$ にて満期正常位自然分 婏した女児で，出生直後右腹部に手拳大，smooth soft， 波動を伴う腫瘤を発見された，腹部単純写真で腸管ガス 像は左方に扁在し，無がス城に石灰化は認めなかった。 逆行性腸管造影にて，盲腸，上行結腸の左上方圧排方認 められ，腎盂造影では，両堅孟正常位置，排泄良好で。 あった. エコーグラムでは Cystic pattern を示した. 生 後 2 週目，脐動脈を使用し，大動脈造影を施行した，悪 性像は認めず，右畉巣動脈が腫瘤に一致して存在した。 この結果右卵巢雒腫と診断し, 開腹手術を施行した. 腹

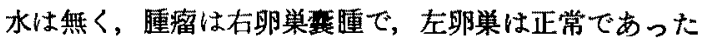


卵巣重腫は $10 \times 8.5 \times 8 \mathrm{~cm}$ ，内容量 $250 \mathrm{ml}$ の単胞性瑟連 で褻腫壁は薄く，緊満し透明な液体であった，病理所見 では Simple cyst であった。新生児腹部隀瘤に於て卵 巣腫湯は稀で Raffensperger に上れば約 7\%に見られる にすぎない，又 Marshall によ机ば新生児期に於る畉巣 腫煌は卵巣售腫が好発すると報告している.しかしなが ら，1971年 Ahmed が53例集計し得たにすぎない。これ ら新生児腹部隀瘤の猃断に於て，各種検查が行われてい るが，血管撮影の進歩に伴い，脐動脈を使用する，大動 脈造影の有用性が高まっていると思われる.

\section{座長のまとめ}

池田 恵一

最初の3 題は小児虫垂桨であったが，小児蛙炎の診 断と治療は古くして新しい問題である. 本症は経過が速 やかで開腹時既に穿孔を拉こしている例が多く，如何に して早期に部断を確実にくだすかは最む大切な点であ る，この点に関し東京女子医大今泉らにより，活湀な討 論が行われたが，広大 1 外石井は，5歳以下の症例では defense を認めるるのが少なく，腹壁祭張の左右差技上 びレ線所見が猃断上有用であるとした とくに注腸造影 で，化膿性変化に先行してりンパ組織の嗹脹の為開口部 が閉鎖され虫垂が造影されず，また回盲部の圧迫による 陰影欠椇和よび盲腸壁の炎定性变化による筩咬像などを 認める之述べた，国立千葉病院外科の山城も，小児蛙 资 31 例中穿孔率は $56 \%$ の高率であるが，本症と内科的疾 患との鑑別診断には，症状からの鑑別は困難で，腹壁緊 張をとらえることが第一であるとし，本症の疑があれば 入院させ，腹部所見を見逃さぬように絽り返し観察する ことが必要であると述べた，小児蛀炎の穿孔例はいら れの病院でも高率であり, 今後単純腹部レ線の梌討, 注 腸造影など他覚的所見の検討が必要である.

小児虫垂炎の術後感染について千葉大児外若山は，腹 腔内菌を検討し，大腸菌，緑膿菌，肺炎桿菌の好気性グ ラム陰性桿菌と，嫌気性の Bacteroides を高率に検出し た. かかる事から穿孔性蜡炎に対する抗生㓲として は，好気性グラム陰性桿菌に対する Aminoglycoside と 泼気性菌に対する LCM (または CLDM) との併用療
法を最適とした。これに対し，名市大外科由良から第 一次選択剤としての LCM または CLDM 投与に批判 的意見が述べられ，また広大石井す，第一次選択として AB-PC, Cephazolin の投与を行い, time response を考 慮した投与方法によって十分目的を達しらる，アミノ配 糖体，LCM，CLDM 等は二次選択剤として慎重に投与 すべきであると述べた，また Bacteroide には C,P す 高率に感受性を有して括り，使用可能との意見むあっ た. 尚，抗生剤の投与方法や作用についてあ討議された が，千葉大若山は，LCM，CLDM，GM を30分以上か けて静注により使用しており，また CLDM 投与による pseudomembrane colitis は未だ経験せず，静注によれば 比較的安全とし，嫌気性菌の培荃固定には 4 日間を要す るので，予防的に早期に使用する必要があると述べた。 抗生剂使用，とくに嫌気性菌に対する抗生剂の使用法に ついては，意見の一致をみず，今後の検討を期待する.

榛原病院外科の竹村は Hernia into the umbilical

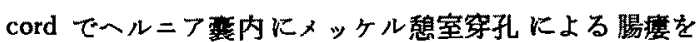
伴った興味ある1例を報告した，本症は小さな刘帯へふ ニフであるが，このような合併奇形を伴らことが多いの でその手術には慎重を要する.

東邦大 2 外久保田は，腣带へルニフ，巨舌，巨大児の 3 主徽を有する典型的な Wiedemann-Beckwith 症候群の 1 例を報告し，内分泌学的検査等にも詳細に言及した。 肺炎で10日目に死亡しているが，本邦では未だ報告す少 なく，今後の症例のつみかさ的を期待する。

都立大塚病院外科の掘は，新生児卵巣变腫て脐動脈加 らのカテーテル挿入による大動脈造影を施行し, 卵巣動 脈の注入血管より卵巣襄腫の術前診断を下し得た 1 例を 報告した．東京女子医大今泉は，新生児巨大卵巣塞腫の 自己経験例で，術前注腸，I．P，Echo，で診断し得た経 験から，動腺撮影は是非必要な検查かと質問したが，城 は，危険性むなく，悪性との鑑別にす出来れば行った方 がよいと述へた，新生児の腹部腫瘤は極めて興味ある所 であるが，脐動脈からの検查は感染予防などに注意して 慎重に行らべきであるら。

\section{第III会場 午後の部}

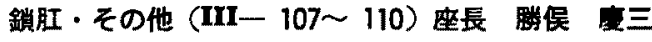 III-107. 鎖肛術後経過の検討}

岐阜大学第 2 外科
今村 健, 山本 真史, 佐治董 豊

国枝 篤郎，坂田一記

教室で経験した鎖肛は33例で，その内訳は高位鎖肛12 
例，中間位鎖肛 5 例，低位鎖肛15例，不明 1 例 であっ た. 性別では中間位, 低位では差がなかったが, 高位で は压倒的に男に多く全体では男22例，女11例であった。 $55 \%$ に合件奇形を認めた。根治手術は高位鎖肛は 8 例に 腹会陰貫通手術を，中間位銷肛は瘦孔のない1 例に会陰 式肛門造設術を，直腸前庭唺を伴える 3 例火 Potts 手 術を，低位鎖肛には会陰式肛門造設術，Potts 手術を各 3 例づつ, 切開術 2 例, cut back 手術を 5 例に行った。 入院中の死亡は7 例であり, その内の 6 例は根治手術前 に重篤な合併症が基で死亡してており，根治手術後の死亡 は1例であった，根治手術25例中生存して退院した24例 の術後経過につき検討を加光以下のこととき結果を得た

1 , 高位鎖肛街後は 5 例中 4 例が下浰㑯向を示した。 2, 中間位，低位鎖肛術後は15例中 7 例哽秘傾向が汉 られた. 3, 便失禁は高位鎖肛街後 4 例中 2 例に2られ た他に，術後排便訓練のまったく不能な知能低下のみら れる低位鎖肛例にもみられた，4，open-tip tube 引き 技き法に上る直晹肛門静止内压検查で肛門部高圧帯は形 成された肍門の括約笳の有無とある程度相関していた。 才なわち腹会陰貫通手術, Potts 手術衍後は 8 例中 6 例 に消失していた，5，直腸肛門内反射子肛門括約筋の残 存する例にのみ陽性であった，しかし反射陽性例でる便 秘傾向を示寸例はあった，6，注腸透視検㚗の側面像で 直腸会陰曲の過度屈曲を示す症例は中間位, 低位鎖肛の 半数以上を占め, 術後の便秘傾向とある程度相関してい た.

III-108. 鎖肛症例の検討, 特に術後肛門機能につい $\tau$

\section{山口大学第 1 外科}

中山 富太, 小田 悦郎, 新谷 清

野村 真一, 八牧 力雄

昭和38〜53年までの16年間に当科で扱かった鎖肛症例 は39例で，男26例，女13例，男女比は 2：1であった。 病型别では低位18例，中間位14例，高位 7 例で，この5 ち死亡はそれぞれ 2 例 (11\%)，4例 (29\%)，3 例 (40 \%)で，高位になるほど高く，全体では23\%となった。 昭和46年までの 4 例は，麻醉および手衍に起因するもの であったが，それ以後は重篤な合併奇型（食道閉鎖, 膀 睄外反など)によるすのであった。

根治手術を施行し，3歳以上となった24人を対象とし て, 主としてアンケートにより術術肛門機能を検討し た. Kelly Code 従が、各病型別に Staining, Accident 怙よび Squeeze を摩価すると低位で1.2，1.6，0.7，合

計3.5, 中間位で1.2, 1.6, 1, 合計3.8, 高位で1, $1.5 ， 2$ ，合計1.5となり fair と判定される結果を得た。 個々の例です poor となった例はなかった。しかし低位 の Potts 氏手術例で Squeeze が弱い1例があった。

術後の直腸粘膜脱は腹会陰式 pull-through 術式の7 例中 6 例にみられ，5ち4例には再成術を要した，最近 行った，中間位に対する仙骨会陰式手術では粘膜脱はな く、これは過剩に直腸を引き降すことがない為と思われ る. (1) Potts 氏手術は術後肛門機能面から不利であ る.（2）中間位に対してい仙骨会陰術式か，粘膜脱を 予防する点でる有利である.（3）腹会陰式 pull-through 衍式では直腸粘膜脱を予防する工夫が必要である。

III-109. 当院における小児鼡径ヘルニア768例の検 討

\section{松戸市立病院外科 \\ 小野 和則, 高井 満, 小䊩 五郎 足立 倫康, 小嶋 邦昭, 增田 政久 \\ 青柳 栄一，丸山卓治}

昭和 44 52年の 9 年間に, 我々が経験した小児巣径 ヘルニア768例について検討した. 全症例の男女比は 2 （514）：1 (254）であり, 前期, 中期, 後期の男女比 はそれぞれ，2.5：1，2.0:1，1.8:1，であった。 発生側は，右側, 左側, 両側の比が全体では 7:5: 1, 男児 $9: 6: 1$, 女児 $5: 4: 1$ であった. 認識年 路の明らかなるの518例のらち，3カ月までに21\%，1 藏までに46\%，2歳までに63\%のものが認織されてい る. 手術時年㱓は，3 3 月末満 のもの $0.8 \% ， 1$ 歳末満 のもの $22 \% ， 2$ 墄未満のもの $43 \%$ と低率である. 整復困 難歴を有するものは，8.5\% (65/768)，男肾9.7\%（50/ $514)$, 女来5.9\% (15/254), であり，3カ月末満に手術 をうけたものの33.3\%，6カ月末満のものの $48.1 \%$ に整 復困難㰮が認められた. 非還納性へルニアにて緊急手 術を施行したるの10例 (1.3\%)，て，1歳未満のもの6 例, 6 力月末满のむの 4 例である. なお, 男児 $0.8 \%$ ( 6 l 514)，女児1.8\%(4/254)であった，当科で用いた術 式は，前期には羊径管の補強を加える方法が70\%であ $\eta$ ，中期より simple herniorrhaphy が70\%となり，こ とに最近 2 年間は Lucas-Championniere 法が80\%を占 めている. 術後合併症は, 発熱 $42 \%$, 陰部腫脹 $4 \%$, 創 感染 $0.7 \%$ ，水腫 $0.1 \%$ 等である. 発熱山，年少児，手術 時間の長いむのに多く，腫脹は, distal sac を処理した むのに多かった．最近三年間は distal sac を残㯰するす のが90\%以上であるが，合併症をみてない，全例に対し 
て施行したアンケート調查の回収率は55\%で，再発 4 例 (0.9\%) であった. 万ち 3 例は前期症例であり, 下腹 壁動静脈の部で sac の結紮を施行するようになった48 年以降は再発0である. 反対側へルニア発生は $8.8 \%$, 辡丸左右不同 $1.5 \%$, 垶丸挙上 $14.9 \%$ あったた。ここ数 年間, 我々は, L.-C. 法を主に用い, 良い成績を得てお。 り，今後も本法を用いたいと考えている. 今後, 更に検 討を加え, 手術成績を向上すべく努力したいと考えてい る.

\section{III-110．停留睪丸の臨床的钼察}

聖路加国際病院小児外科 伊藤 正幸

停留寡丸は造精機能障害, 悪性化と関保し臨床的に重 要な疾患であり, 男子性器奇形の中で最も多いが，その 訅断方法，治療方針において見解の統一をみていない． 今日当院に打ける過去 8 年間の本症102例 (手術例82例) を検討し，当院小児外科にて現在行なわている手術方法 を中心に報告する.

停留部位は Bill の分類を用いた. incanal type が67 \%を占め, intraabdominal type は1例のみであった. 左右差はなく両側対片側の比は 1 対 4 , 共存するールニ フは $83.5 \%$, 辠丸の萎縮は33\%, 副㐿丸の異常は $14 \%$ あ り合併する奇形は，6\%にみられた．発見時年龄は生直 後, 生下時が大部分で, 手術時期は 3 歳から 8 歳にあり 5 歳がピークとなっている. 手術時期の決定は造精機 能, 手術後の追跡調查の報告, 手術時精管, 血管損傷と いう手枝的な観点から, 就学前の $5 \sim 6$ 歳か洷適年齢と 考えている. 当院では現在 Alexander H, Bill による 辡丸固定術を用いている.これは 4 つの step よりな り, 第 1 は Hernia sac の処理, 第 2 は Cord structure 周柬組織の剝離，第 3 internal ring を外側に開き， 血管を後腹膜腔内へ剝離をすすめ, 第 4 に精管血管を inferior epigastric vessels の下を通し内側へ移動する.

陰唓内固定は陰襄と皮つとの間に固定する Scrotal pouch formation を用いている. 当法では血管を angle をつくる ことなく陰哓内に対して最短距離を得るための transposition に他ならない.この目的のため最合理的な方法で あり，その最大のポイントは後腹膜腔内へ血管を剝離す ることである.この手技が危険であるとの意見もあるが $5 \sim 6$ 歳の年路と, 注意深い操作により, 当法で行なわ れた62例では血管損傷は 1 例も見られなかった。

\section{座長のまとめ}

腾俣 三

鎖肛術後成續の評価法は Kelly の score を始めと し, 各施設で独自の score を作製し，また客観的評価
法として直腸肛門内压測定あるいは注腸所見で行なわれ ている. III-107の演者は臨床症状，直腸肛門内圧およ び注腸所見で，II-108おるに Kelly の score に準じ たもので評価している. 鎖肛は病型, それに対する手術 方法, 術後観察期間により成績がことなることは明らか なことである.したがってできれば score も全国的に 統一し，客観的評価も基準を設け，病型に対しては小児 外科学鎖肛病型検討会に準じ分類し討論すれば，各施設 のみの評価でなく，扣互に治療方針，治療成績等も比較 検討できるのではないかと思う.

III-109は 9 年間における治療法の変遷を 3 期に分け 検討し反省を含めての発表である，小児単径へルニフは 普遍的な疾患であるが，手術時期，手術方法等未だ問題 が残されている. 演者は経験した合併症よりみて Lucus Championiere 法が最良であるとのべた. 本症に対する 術式は現在演者らと同様に high ligation を主とした方 法が一般的であり，前壁補強はとらえられてないと考え られる. 会場より再発防止には high ligation の目標を 深下腹壁動静脈のレペルで行らことが重要であると演者 を含め発言がみられた．また内鼡径輪の大きいものは内 輪の縫縮あるいは前壁を補強する必要があるとの発言す あり,この再発防止を含めて手術時期, 自然治癒等も今 後の検討が望まれる.

IIIー110は停留等丸に対する Bill 法の詳細な説明と 利点をのへ，その治療成績を発表し，造精機能および手 術手技の困難性からみて手術時期は 5 ～ 6 歳が至適年龄 であるとのべたままた手術手技に関し睾丸を充分陰襄内 に下降させるには Spermatic vessel の遊離が極めて重 要であることを強調した，手術時年踰について未だ議論 のあるところで会場より $1 〜 2$ 歳でも何ら問題なく，ま た障害なく手術し得るもので，もっと早期に手術をすべ きでないかと発言があった.この手術年制は本邦では最 近低くなりつつあるのが現況で問題がないようであるが 術後長期の follow up を行い精腺機能を精査し, 年齢 的影響を検討し，慎重に手術時期を決めるのが望ましい と思われた.

小児・肝・胆道 $($ III 111 114) 座長 由良 二郎

III-111. 小肾特発性胆汁性腹膜炎の 1 治験例 大森赤十字病院第 3 外科

○井磧 進, 根岸 征示 渡辺 春子, 陳

小児の胆汁性腹膜炎は稀れな疾患で，しばしば重篤な 症状を呈する．本症はイレウスその他の急性腹症や自家 
中毒症との鑑別がさづかしく，開腹によりはじめて跈断 が可能となるもので，早期適切な処置が重要である. わ れわれは最近手術により救命し得た本症の 1 例を経験し たので，症例の報告とともにいささかの洘察を加劣る.

症例は 4 歳女児. 主訴は䧗痛之呕吐．既往に自家中毒 症. 昭和52年11月14日より発熱, 腹痛, 頻回のコーヒー 残渣梯呕吐をきたし，11月18日当院小児科入院. 白血球 数 11,400 , 急性腹症として11月19日当科入転移，祭急手 術施行。胆素管壊死に上る胆计性腹膜次と急性滕炎. 胆 垔外漊術と腹胿ドレナージ. 術後の胆道造影で総胆管膵 管合流異常を認めた。術後第 3 病日，腹腔内胆汁渗出の 減少をみないため再開腹. 胆鹖剔出と胆管ドレナージ施 行. 術後 49 病日治瘾退院.

\section{考按}

1. 総胆管脺管合流巽常を伴った小児胆道穿孔につい ては，大川（昭51）が3例を報告しているがかれわれ の症例も胆管勝管合流異常が本症の発生要因の1 つと考 える.

2. 小児膵炎と胆道吩孔の関連については，既飞 Blumenstock（1957）が注目しているが，冁告例は少く， 塩川（昭10），水越（昭41）の報告がある.

3.われわれの症例は，脺炎之胆管壊死で，胆管壊死 部の処理で今回は切り抜けたるのの, 胆管奕管合流異常 の問題はな戚って列り，今後の経過を観察中である。

III-112. 10才と3オの女児に歌められた総胆管・膵 音合流暴常症例

○横田 勝正, 長島 金二, 池田 舜一 高田 悦雄, 小松原利文, 谷恒 明 日高 知昭, 武藤 邦彦, 池口祥一 松讯 良和, 荒川 征治, 信田 重光

先天性胆道搪镸症は欧米より日本に多いと言われてい る. 主に小児に認められる胆道疾患は先天性形成異常 の面から胆道閉鎖，総胆管萣腫，総胆管末端部の先天泩 㹨窄らにわけられる、まだ原因がはっきりつかめないる のが多い中で, 最近滕・胆管合流異常が術中造影及び内 視鏡の発展と共に報告されるようになってきた。これは 先天性胆道払張症の原因の一端をにならものと注目され る. 我々は最近 2 例の同症例を認めたので報告する. 10 歳と 5 歳の女児である. 両者とす反復性黄㾝, 腹痛, 呕 吐, アミラーセ値の上昇らの臨林的経過をむっている. 術前血沈検查では WBC の上昇, GOT, GPT, LDH Al-p らの高値が正常化する中で Al-p のみが高値のま

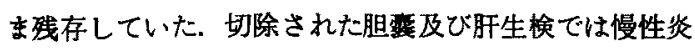

症性変化が軽度認められる程度であったまた胆计培養 は陰性であった，前者は乳頭より $4 \mathrm{~cm}$ の膵管の部に 総胆管が開口していた。後者は乳頭近傍の扗張部が約 $3 \mathrm{~cm}$ 認められる所に総胆管末端部が㹧害を示す型で開 ロしていた。 また脺管も同部に開口していた.これら2 例共大井の分類でいくと B 型に属すると思われる. 結論 として, (1) 小児において反復する黄㾝, 疼痛, アミラ 一ぜ值の高値の際恃本疾患を疑 う. (2) 内視鏡て十二指

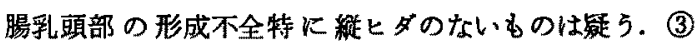
ERCP を行らが小児には困難な場合がある為術中造影 で乳頭部所見に注意する. (4) 小児用ファイバースコー プの開発が待たれる. (5) 手術は胆道狭窄として安易に 内瘦術，乳頭形成術ですをせると不充分な手術に終って 再発がまぬがれい症例があるので Roux-en-Y 䀛合が 最むよいと思われる.

我↔の 2 症例亡b胆亳摘出術, 総胆管空腸吻 合術 (Roux-en-Y 吻合) を行って膵液と胆汁の流出を别々に 流すようにした.

\section{III-113．小归門㟲圧穴進症の治萧経联}

大阪大学第 1 外科

$\begin{array}{lll}\text { 吉川 } & \text { 澄, 鎌田 } & \text { 振吉, 池田 義和 } \\ \text { 而田 } & \text { 正, 川島 康生 }\end{array}$

小児門脈圧六進定に於いてては，一般には，成人に比 へ，肝硬変によるるのは少なく，肝前性のブロックによ るものが大部分を占めるとされている. 又, その治療， 殊に手術治療については，末た確立されていないのが現 状である.しかしながら, 初期症状が多量の消化管出血 である事がしばしばあり，早期に適切な処直が必要と なってくる.我々の教室に抽いて，過去10年間に経験し たり小児門脈王六進症は，12例で，らち手術を施行した のは， 7 症例であった. 手衍症例の内訳は，肝前性のむ ○ 2 例, 肝硬变症 1 例, 又, 先天性胆道閉鎖症術後の 門脈圧穴進症は 4 例であり，これらの症例に対して， Mescocaval-shunt 2 例に, Portocaval shunt 1 例 に，摘脾十副血行路遮断術を 4 例に施行した. 今回これ らの症例について，術式及び経過等に関して検討を行 なったので，その結果につき報告した。

\section{III-114．小児門脈圧穴進症手㫱例の検討} 新潟大学第 1 外科

高野 征雄, 吉田 车介, 阿部 要一 村山裕一, 塚田一博, 岩㵹真 武藤 輝一

富山医薬大外科 伊藤 博 
数室で経験した小児門脈王立進症手術例（発症が15歳 未満例) は19例て，特発性門脈王六進症12例，肝前性門 脈閉塞症 4 例, 肝硬変症 3 例 (1 例は先天胆道閉鎖症の 衍後)であった，手術時年龄は1歳 8 カ月から23藏（平 低10.3歳) で男13例女 6 例, 術中門脈王は最低250最高 $520 \mathrm{mmH}_{2} \mathrm{O}$ (平均 $385 \pm 92 \mathrm{mmH}_{2} \mathrm{O}$ ) であった. 食道静 脈瘤とその出血の頻度はそれぞれ78.9\%，63.2\% と高 かった.

教室では現在食道静脈瘤に対して直達手術を施行して いるが，吐血で来院した 9 例の小児例に対して，東大 2 外法 7 例を信む食道離断術を施行し, 手術死. 術後再出 血ともになく全例生存（最長13年経過）し良好な結果を” 得た.このうち 1 例は, 度重なる出血を繰り返した 1 藏 8 カ月の肝前性門脈閉塞症例で, 東大 2 外法を施行し術 後 3 月の追跡期間であるが良好な经過をたどってい る. 過去に扣い，て脾摘術 9 例，脾腎静脈吻合術 3 例を施 行したか，術後 4 例に再出血（術後17年，14年，10年， 8 年）を胃，3 例を緊急食道離断術で救命した，再手術 で救命し得た 3 例を除くと，現在生存者は 2 例といら傪 娢たる結果であった，一般に小児門脈厈六進症は，肝夷 質障害の少い例が多く，その予後は比較的良好な場合が 多い:しかし成人例に比して食道静脈瘤及び吐下血の頻 度は高く，食道静脈䩗に対する適切な外科治療を行わね ばならない，我々はこれまで，主として成人の門脈圧六 進症に対する直澾手術の有効性を報告して来たか，経胸 的食道離断術は，䇣急例でも比較的安全に行われ，旦つ 充分な止血効果があり，小玧門脈生六進症に対しても充 分な適応があると考える。

座長のまとめ

由良 二郎

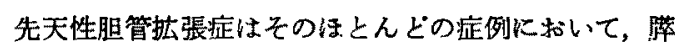
管・胆管の合流異常が存在することが， ERCP, PTC, 術 中造影などによって明らかにされ，应張の原因が胆管内

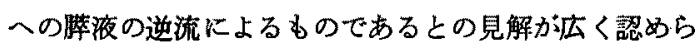
れて来た，またこの合流異常には種々の形態があって， いまだ統一される段階には至っていない，成人例におけ る大井の分類も引用されたが，小児においてはなお検討 を要するところで，十二指腸内視鏡による乳頭の確誌が 重要である.

また本症における自然穿孔例が報告されたが，穿孔の 原因屾逆流した脺液による胆管壁の炎昰性変化によると の見解が述へららた。勿論大きい霜陲を伴ら例に於いて は打撲などによる腹压の、上昇も否定出来ないななお自然 穿孔の発生部位か䏣表管付近に存在することが多い点は
鼠味が梁い.

合流異常例の手術々式については勿論払張部を切除す ることが大切で，繄急手術によりドレナージのみで処理 された境合には，再呀孔，癌発生の問題む充分考慮され るべきである.

小児門脈王立進症は従来より肝前性のすのが多い点は 周知のところであるが，近年胆道閉鎖应の根治手術が数 多く施行されるようになって，肝硬変に由来する定例の 報告む目立って来ている。

肝前性のむのには shunt 手術が良好であると報告が あったが，吻合血管の patency が問題であり，新大か らは特発性のものに対する shunt, splenectony の逗隔成 績は不良であり，東大式 davascularisation の有用性が 述べられた．現在これらの治療成績は各施設によりまら まちであり，術式ならびにその道庆については今後十分 検討されるべきことを痛感する。

小児肝・胆道・その他 $(\mathrm{III}-115 \sim 120)$

\section{座長 酸河敬次郎}

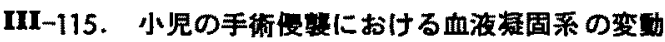
（特にフイブリノーゲンを中心として）

昭和大学外科

李 雨元,八塚 正四, 永井 正彦 岡松 男, 石田 正統, 石井 淳一

東京工業大学 岡本 宽, 稲田 祐二

目的：小児に和ける手術侵襲前後の血液频固系の变動 をフィブリノーゲン（Fbg）を中心として䋡璟を加光 た. 対象は生後 1 週生での正常成熟新生児 9 例, 外単径 ヘルニア手術16例, 開腹術例21例 (学童, 幼児 7 例, 乳 児 5 例，新生児 9 例 5ち未熟児 4 例）であり Fbg の測 定は稻田の方法を用いた。

結果 : 正常成熟新生児例については少数例の為明らか な傾向はみいだせ得なかったが，生後日数增加とともに 上昇する傾向ともみられ，51 mg/dl〜 750 $\mathrm{mg} / \mathrm{dl}$ 值を示し た. 外崢径ヘルニア手術例については術前, 術值後, 術 後24時間までについて険討したが，1/3は術值後に術前値 より減少するが術後24時間にははとんとの場合術前值を 上まかって扣り平均 $37 \mathrm{mg} / \mathrm{dl}$ の上昇を示した．開腹術例 については, 学童幼児例は術直啳術前值より減少したの ら, 術後 $1 \sim 3$ 日後に術前值を上まわって上昇しピーク を示したのら以後 7 日までには術前值に復する傾向を示 した 乳児及び新生児, 未熟児例は学童例に比べ術前值 低い場合が多く特に新生児，未熟児例の $2 / 3$ は 200mg/ dl 以下の値であった。手術侵㜔下の变動については, 2 
群に分れる傾向を示し, 術中出血冝か $10 \mathrm{ml} / \mathrm{kg}$ 以上の場 合学童類似の変動を示すが $10 \mathrm{ml} / \mathrm{kg}$ 以下の場合は術後, 術前值を上まわるがその程度は軽度であった，一方開腹 術21例中術後 Fbg 值が減少のみを示与泟例は 1 例のみ 認められたが。この症例は術後8日目にDIC を併発死 亡した。

結語：(1) 新生児，未熟児においては術前より低 Fbg 血症を示す場合が多い（2) 新生児未熟肾の手術侵襲 下に括ける生体反応としての Fbg の変動認められる が，年長児に比べ軽度である. (3) 個体差の著るしい絶 対値よりる経時的観察が臨床検査上の一指標としては大 切である.

III-116．小児の肝胆道系疾思における ${ }^{99_{\mathrm{m}} \mathrm{Tc}-\mathrm{Sn}-}$ Pyridoxylidenisoleucine (P.I) による診断

静岡県立こども病院外科

河野澄男, 中川 敏行, 竹内 俊二

藤原 利男, 福田 昭

同核医学室 天野 正幸

近年, ラジオフイントープ (以下 RI) の診断手技が 確立されるとともに，小児の RI 診断も急速に実施さ れるようになってきました. 今回，われわれは特に小児 の肝胆道系疾患の踰断に有用であった半減期の短かい， 大量投与可能な, 従ってイメージングの良好な ${ }^{99} \mathrm{~m} T \mathrm{Tc}$ Sn-Pyridoxylideneisoleucine (以下 ${ }^{99 m} \mathrm{Tc}-\mathrm{P}, \mathrm{I}$ ) を用いて 興味ある知見を得たので報告します。昭和52年 6 月より 昭和53年 6 月までに静岡こどす病院で経験した症例数は スライドに示すよらに先天性胆道閉鎖症 4 例, 胆道拡張 症 7 例，乳児肝炎 6 例，胆道ジスキネジー1例，胆管 hypoplasia 1 例の合計19例を対象としました，方法とし

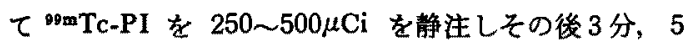
分, 以後10分每にシンチスキ+ンしました，症例により 静注後長時間にわたって観察致しました.

先天性胆道閉鎮症では，肝影の描出はみられるが240 分経過しても胆管, 胆の5, 腸管への排出は全く認めら れなかった，乳児肝炎では所の描出は早いが，胆のう， 胆管，腸管への排出は緩慢であったが，ほとんどの症例 に腸管への放射性活性が証明された，胆道抎張症に拄い ては抾張部位は鮮明に描出され肝内胆管桩張状態も明瞭 に描出した，本剤は被曝線量も少なく，短時間て解明な 像が得られ，小児重症黄疸例にも安全に用いられる薬郕 である. しかし閉塞性の強い症例ではかならずしす满足 のいく結果が得られなかったことより，今後とも症例を かさねて検討しなければならないであるう。
III-117. 99 Tc Phytate による小児肝シンチグラム の検討

都立清瀬小児病院外科

石田 治雄, 重城 明男, 伊藤 泰雄

猪原 期行, 鎌形正一郎, 井上迪産

北里大学 石井 勝己

昭和 48 年 8 月か 5 昭和 53 年 7 月迄に生後 2 日目から 15歳迄の小児106例に198回の肝シンチグラム検査を行っ た.このうち179回は ${ }^{9 m}$ Tc Phytate を使用した.

限局性肝疾患では, 悪性尰湯33例飞72回, 良性稙瘍 5 例火14回，計38例に86回のスキャンを行った．悪性腫煌 で忙神経芽細胞腫, 肝腫瘍, Wilms 腫痬の所謂 3 大腫 瘍28例中21例75\%k陽性所見が経過中に得られた。

肝位置異常症例では11例に11回のスキャンを行い診断 がついた，右横隔膜下膿瘍には ${ }^{99 \mathrm{~m}} \mathrm{Tc}$ MAA を併用す るとよい.

ビマン性肝疾患には57例に101回のスキャンを行った. 肝シンチグラム正面像を熊野の報告に従い7型に分類 ᄂ, 先天性胆道開鎖远生存例，死亡例，肝炎，総胆管㹡 張症なとにていてみると，肝炎や総胆管拡張症の大部分 は I 〜I 型であり, 先天性胆道閉鎖症生存例はIV〜V型 が，死亡例は60\%近くがVI型であった。経時的に肝シン チグラムとみると死亡例はI型から杖型に変化してゅ $<$.

胆シンチクラムを経時的に撮ってゆくことにより，腫 㾴症例やビマン性肝疾患の病状が把握出来，予後をある 程度推測することが出来る.

III-118. 小䝨肝癌の臨床的 - 病理学的换討 北海道大学第 1 外科

○秦 温信, 内野 純一, 池田 雄祐 宇根 良衛, 内藤 春彦, 品田 佳秀

佐々木文章, 佐藤 光一, 葛西 洋一 市立札㹸病院外科 手戸一郎

国立札幌病院外科 上村 女也

小児肝癌の根治的治療は肝切除以外にないが，成人の それに比し切除率が高いのが特改の一つである. しかし ながら全体としてその予後はいまた満足すべきのでは ない，そこで本症の治療成績向上のための諸因子につい て検討したい。

対象拉よび方法：最近20年間に北大第 1 外科で治療を 行った小児期肝悪性盾湢は, 原発性21例, 捏移性15例, 計36例である. 原発性のうち小児肝癌は20例で, 肝芽 睡 12 例, 成人型肝癌 6 例, 不明 2 例である. これら症例 


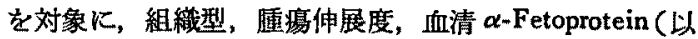
下 AFP) などと子後との関係について検討する.

成績和よび結語：稙留の占居部位と切除率との関俰で は，2区域までのるのの切除率は3/3(100\%)，3区域 のもの3/6(50\%)，4区域のもの0/5(0\%)で，全体の 切除率は56\%である.

これら切除例10例のうち，前半10年のむのでは，手術 による合併症および再発により全例 4 力月以内に死亡. 後半10年の 4 例では, 長期生存期待例 2 例で, 再発した 他の 2 例 強力な化学療法などで 1 年以上の生存をみて おりここれは手術手技および患者管理の向上に負うとこ ろ大である.

後半10年の切除例 4 例について AFP 減衰曲線から 半減期を求めると, 長期生存期待例のそれは4.6日以下 であり，再発例のそれは6.0日以上であった。これより AFP 術後半減期の測定は手術の根治性湘定に有用之思 われる。

組織分化度と術前 AFP 值との関連を, 腄煌重量 500 $\sim 700 \mathrm{~g}$ 前後のあのについてみると, 生存例では高分化 型組織成分が50\%以上のもので，術前 AFP 值は87 $\mu \mathrm{g} /$ $\mathrm{ml}$ 以下であり，術前 AFP 值は組織型掞よび予後と関 連があるように思われる。

以上，尰湯 marker として AFP の利用により，さら に治療成績の向上が期待できる。

\section{III-119. C.T. による神経芽細胞堙眼窝転移の検討} 名古屋保健街生大学外科

$\begin{array}{lll}\text { 山口 茂, 伊藤 } & \text { 寛, 片田 和広 } \\ \text { 岸川 輝彰, 戸田 孝 } & \end{array}$

同教射線科 古賀 佑彦 名古屋市立大学第 2 外科 角岡 秀彦 卜ヨタ病院外科

牧原 良行, 安藤 重满

我々は，神経芽細胞腫眼㸗転移の2 例にコンピュー ター断風撮影（以下 C.T. と略）を施行 L, 興味ある知 見を得たので報皆する.

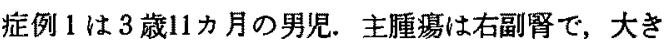

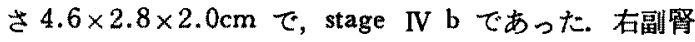
摘出後 6 力月目に両側眼球突出，眼䁐溢血斑が出現した ため, C.T.スキャンを施行した.

症例 2 は 4 歳10力月の女先. 雨側眼球突出にて脳外科 受猃L，C.T、Kて症例 1 と類似 $の$ 所見を呈した為, 神 経芽細胞腫眼䆟転移を疑い当科に入院した，精查したと ころ，右副腎に大きさ $1.7 \times 1.5 \times 1.5 \mathrm{~cm}$ の重湯が認め
られた. Stage IV b であった

眼倣部の C.T. 所見は, 両症例共, 両側眼裔の外一後 側壁に治って隀璄陰影を認め,これにより眼球が内前方 に突出していた，初回検查時には上下眼窝裂及び骨への 明膫な浸潤像は認められなかったが，症例 2 では，1カ 月後に㾝疸は眼窩上方に達し，周囲骨の破壊像が認めら れた. 以上の C.T. 像は視神経を中心とする眼䆚腫場と は全く異なった像を呈していた．従来本症の眼球突出 は，眼窩周辺及び頭蓋底の骨転移によると言われてい た.我々が経験した 2 例は，頭部の病理解剖を行ってい ない為，C.T. 像のみから病像を判断せざるを得ないが， 転移形成早期には，眼盆外一後側壁に沿った軟部組織に 出現し，それによる眼球の内前方への圧排を来たし，さ らに周团骨への浸潤が生ずると考えている.

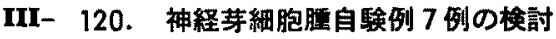
昭和大学外科

○四ッ谷敏明, 金 義孝, 三浦 純一 网松 孝男, 石田 正統, 石井 淳一 藤力丘病院外科 兽根田靖昭

我国に和ける小児覀性固型尰瘍中最る頻度の高い神释 芽盾に対する 治療は，近年著しく向上しつつあるが正 期，IV期の進行例に怙いては满足すべき結果は得られて いない，そこで我々は，最近 4 年間に経験した向期，IV 期の神経芽隀 7 例の治寮方法の検討及び予後に拉よぼす 影響について報告した。

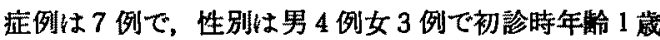
未満 4 例， 2 歳か５７歳が 3 例，全例腹部腫瘤が主訴で あり，原発部位は，副腎 4 例，後腹膜，骨盤部，不明例 各 1 例，病期分類 2 III期 2 例，IV期 4 例，IV-S 期 1 例 であったここの内公期 2 例，IV期，IV-S 期各 1 例が生 存中であり，他 3 例は死亡例であった，入院時検査所見 ては，末梢りンパ球数 3,000 以上，LDH 值1,000単位以 下の 4 例が生存中である. 組穖分類では，IV-S 期の不 明例を除き，N．B，4例，GNB 2 例で内生存例は N.B 2 例，GNB 1 例であった，畽瘤全摘例はIV期 2 例のみ て内 1 例が死亡, 他の 4 例は全摘不能例で四期 2 例に は, Reduction Surgery が行なわれ，内 1 例は 2 カ月後 イレウスで再開腹した時には残存隀瘤は消失しており， Reduction Surgery が有効であったと者えられた。化学 療法は，1例を除き術前 VCR の one shot 法, 衍後 は, James 療法を行なった。最近では免疫学的療法る 積極的にとり入れつつあり，PHA 幼若化能の測定も行 ない，その影響について検討を加えている. 以上経験例 
III期，IV期 7 例から予後判定因子を考えると, 初讋時 1 歳未満, 副腎原発以外, 末梢 りンパ球数 3,000 以上, LDH 值 1,000 単位以下の症例が生存例であり，予後推定 上重要である点を強調し，最後に期例で全摘不能例飞 奶し，Reduction Surgery が有奻であった症例を紹介し t.

\section{夾長のまとめ}

河野 澄男

III-115(昭和大学外科，李他 7名) 小児に於ける手 術侵襲前後の血液凝固系の変動をつィブリノーダンを中 心として検尉を加えた. 先す測定法であるが，従来のチ ロジン法にくらべ稲田法によるフィブリノーゲン測定法 で一番の利点は測定總了まで 2 分以内といら短時間て测 定が可能なことと clottable fibrinogen を正確に反映す る点である. 特に重要な点は新生児, 未熟児のフィブリ ノーケ゚ンの手術漫襲に対する反応が年長児にくらべ軽度 に上昇する点である，尚検討中であるが肝臓をはじめ生 体代謝の未熟性が関与するるのではないかと推湘してい る. 血液凝固系を論ずる場合, 種々の因子が存在するの で結論ずけることはむつかしく今後の枱討が必要である 5 .

II-116（静岡こども病院，河野他 5 名）小览の肝胆

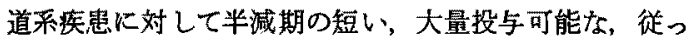
てイメージングの良好な ${ }^{99 \mathrm{~m} T c-P . I}$ I 使用して診断に 有用であったと速べている. 先天性胆道閉鎖症で肝影は 早く描出したが，240分経過しても胆管，䏣のう，腸管 への排出は全く認めず，乳児朋焱では肝影の描出は早い か䏣管，胆の5，腸管への排出は緩慢であったが全例腸 管への排出が先天性胆道閉鎖症と異なる点であったと報 告した，高橋氏（千葉大小児外科）は本剤の有用性を認 めても胆道閉鎖应と乳児肝炎の鑑別には充分でないと述 べている. 胆道扗張症例では肝内肝外胆管像はともに鮮 明な像が得られた。

III-117（清瀨小児病院，石田他 6名）小児外科領域 に於ける肝シンチグラムで, ${ }^{99 \mathrm{~m} T c}$ phyfate を使用して 96症例, 177回施行した. 肝内限局性病変, 更にはび漫 生肝疾患等多数の症例に対し診断的に有用であったと報
告している. 特に先天性胆道閉鎖庭の経渦観察などでは 本剂の方が有効であると述べている.

II-118（北大第 1 外科，秦他10名）小児肝癌に対す る治療成績についての問題点についてあらゆる面から模 討された，特に組織型，病期，AFP 值等の面から生存 例について速べている. 後半 10 年間に於ける治療方針に 著变はないが，術後 1 カ月〜 2 カ月は AFP 值半减期を わって，その後は AFP 檤の上年をるって再発を馀断 し，化学療法，その他の治療を開始すると述へてている. AFP 值半減期は肝切除手術後の根治性を示す有力な指 摽上されている。半減期が3.5日でる術後転移を来たし 死亡した症例の報告むあり，AFP 值の変動については 充分の注意を要する，岡松氏（昭和大学外科）より再発 小先肝癌に対する持続動注治療法についての質問があ り，秦は腫場の縮小奻果は mild であったがこの症例は 末期であったのでそのような結果となったと報告した。

III-119（名古屋保健大，山口他 8名）神経芽細胞腫 眼窝転移の 2 例に computed Tomography (C. T.) を施 行し興味ある所見を報告している. C. T. の所見で眼宫 部の軟部組織に転移巣が出現したと報告したが，同様の 症例を経験熏大石田氏（清瀬小児病院）は骨転移かある

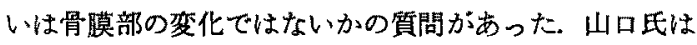
骨㷬からの連続性怯認めなかったと述べ，C．T、での分 析でも今後更に検討の必要があると考えられた。

III-120（昭和大学外科，四高他 6 名）神経芽細胞

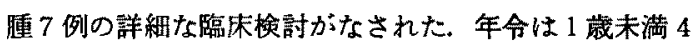
例， $2 \sim 7$ 歳 3 例，原発巣恃副腎 4 例，骨盤整 1 例，不 明 1 例, 病型 III期 2 例, IV期 4 例, IV-S 期 1 例, 生存 例では街前 LDH 值は全例1,000以下で末梢りンパ球数 は3,000以上であり術前化学療法が全例に行われていた。 神経芽縕胞腫の予後判定因子としては LDH 值, 末梢り ンパ球数がある程度の指標になると報告している.

又期の腫煌全剔出不能例においてす reduction surgery が著効した例むあり進行例でる皘極的に手術を施 行していると述べている.

\section{第 $\mathbf{V}$ 会場 午前の部}

消化管出血 $(V-81 \sim 85)$ 座長 勝見 正治

V-81. 診断の困難であった消化管出血の4 例 自治医科大学消化器外科
村上 幸司，金城 康夫，川田 克也 天目 純生, 签原小五郎, 宮田 道夫 柏井 昭良, 森岡 恭彦 